\title{
On the circulation, water mass distribution, and nutrient concentrations of the western Chukchi Sea
}

Jaclyn Clement Kinney ${ }^{1}$, Karen M. Assmann ${ }^{2,3}$, Wieslaw Maslowski ${ }^{1}$, Göran Björk ${ }^{2}$, Martin Jakobsson ${ }^{4}$, Sara Jutterström ${ }^{5}$, Younjoo J. Lee ${ }^{1}$, Robert Osinski ${ }^{6}$, Igor Semiletov ${ }^{7,8,9}$, Adam Ulfsbo ${ }^{2}$, Irene 5 Wåhlström ${ }^{10}$, Leif G. Anderson ${ }^{2}$

${ }^{1}$ Naval Postgraduate School, 833 Dyer Rd., Monterey, CA, 93943, USA

${ }^{2}$ Department of Marine Sciences, University of Gothenburg, 40530 Gothenburg, Sweden

${ }^{3}$ Institute of Marine Research, P.O. Box 6606 Langnes, NO-9296 Tromsø, Norway

${ }^{4}$ Department of Geological Sciences, Stockholm University, 10691 Stockholm, Sweden

$10{ }^{5}$ IVL Swedish Environmental Research Institute, Box 530 21, 40014 Gothenburg, Sweden

${ }^{6}$ Institute of Oceanology, Polish Academy of Sciences, 81-712 Sopot, Poland

${ }^{7}$ International Arctic Research Center, University Alaska Fairbanks, Fairbanks, AK 99775, USA

${ }^{8}$ Pacific Oceanological Institute, Russian Academy of Sciences Far Eastern Branch, Vladivostok 690041, Russia

${ }^{9}$ The National Research Tomsk Polytechnic University, Tomsk, Russia

$15{ }^{10}$ Swedish Meteorological and Hydrological Institute, Norrköping, Sweden

Correspondence to: Jaclyn Clement Kinney (jlclemen@nps.edu) and Leif G. Anderson (leif.anderson@marine.gu.se)

Abstract. Substantial amounts of nutrients and carbon enter the Arctic Ocean from the Pacific Ocean through Bering Strait, distributed over three main pathways. Water with low salinities and nutrient concentrations takes an eastern route along the Alaskan coast, as Alaskan Coastal Water. A central pathway exhibits intermediate salinity and nutrient concentrations, while

20 the most nutrient-rich water enters Bering Strait on its western side. Towards the Arctic Ocean the flow of these water masses is subject to strong topographic steering within the Chukchi Sea with volume transports modulated by the wind field. In this contribution we use data from several sections crossing Herald Canyon collected in 2008 and 2014 together with numerical modeling to investigate the circulation and transport in the western part of the Chukchi Sea. We find that a substantial fraction of water from the Chukchi Sea enters the East Siberian Sea south of Wrangel Island and circulates in an anticyclonic direction around the island. This water then contributes to the high nutrient waters of Herald Canyon. The bottom of the canyon has the highest nutrient concentrations, likely as a result of addition from the degradation of organic matter at the sediment surface in the East Siberian Sea. The flux of nutrients (nitrate, phosphate, and silicate) and dissolved inorganic carbon in Bering Summer Water and Winter Water is computed by combining hydrographic and nutrient observations with geostrophic transports referenced to LADCP and surface drift data. Even if there are some general similarities between the years, there are differences in both the temperature-salinity and nutrient characteristics. To assess these differences, and also to get a wider temporal and spatial view, numerical modeling results are applied. According to model results, high frequency variability dominates the flow in Herald Canyon. This leads us to conclude that this region needs to be monitored over a longer time frame to deduce the temporal variability and potential trends. 
https://doi.org/10.5194/os-2021-43

Preprint. Discussion started: 25 May 2021

\section{Introduction}

The Arctic Ocean has experienced large changes in recent decades with a decrease in summer sea ice cover as the most prominent, impacting a number of processes including the functioning of the ecosystem (e.g. Meier et al., 2014; Kwok, 2018). More open water decreases the albedo which amplifies warming (Kashiwase et al., 2017). To some degree this change in albedo is compensated for by more cloud formation caused by increased evaporation from the open water. The melting of sea ice is mainly caused by atmospheric forcing (Ding et al., 2017), but inflow of warm surface water from the Atlantic and Pacific Oceans (see Fig. 1a for the general circulation), also plays a role, as well as the heat mixed up into the surface ocean from deeper layers (e.g. Polyakov et al., 2013, 2017; Stroeve and Notz, 2018). The temperature of the Atlantic Water entering the Arctic Ocean through Fram Strait has varied over the last decade with an increasing trend overall (e.g. Wang et al., 2020). On the other hand, the three-dimensional structure of the flow and property transport through Bering Strait is much less known

45 (Clement Kinney et al., 2014). One reason for this deficit is the difficulty of having sustained measurements in Russian waters. Limited long-term mooring records between 1990-2019 indicate an increase in volume transport as well as a winter freshening and spring warming (Woodgate, 2018; Woodgate and Peralta-Ferriz, 2021).

One essential question related to Arctic warming is how the regional system might feedback to the global climate system.

50 These feedbacks could either be changes in ocean circulation, notably deep water formation and its impact on the thermohaline circulation, the changes in albedo with decreasing summer sea ice coverage (Wang et al., 2020), or through changes in the sources and sinks of greenhouse gases like carbon dioxide and methane. The marine sink of carbon dioxide is determined by ocean circulation, but also by changes in the ecosystem, including primary productivity that has recently been reported to intensify due to elevated light conditions when the sea ice vanishes or gets thinner (e.g. Arrigo and van Dijken, 2015; Clement

55 Kinney et al., 2020). Arctic Ocean primary production is often limited by nutrient supply (e.g. Anderson et al., 2003; Mills et al., 2018) with external sources from the Atlantic and Pacific oceans, as well as river runoff. Furthermore, nutrients can be supplied to the surface water from below by mixing that, in turn, can promote primary productivity (Williams and Carmack, 2015). However, the nutrients in the subsurface waters often have a source of organic matter mineralization, a process that also produces carbon dioxide. Thus, this path of primary production might have less impact on the oceanic carbon sink,

60 stressing the need to assess the contribution of the external sources. The Pacific inflow has higher nutrient concentrations than that from the Atlantic (e.g. Wilson and Wallace, 1990), but has a significant deficit in nitrate relative to phosphate due to denitrification in the upstream regions (e.g. Kaltin and Anderson, 2005). Additional denitrification also occurs in the Arctic shelf seas, thus further contributing to this nitrate deficit (Anderson et al., 2011).

65 Pacific Water enters the Chukchi Sea through Bering Strait (Fig. 1a) in three water masses of different properties: Alaskan Coastal Water, Bering Shelf Water, and Anadyr Water (e.g. Coachman et al., 1975). Of these, Bering Shelf Water and Anadyr Water partly mix north of Bering Strait to form what is known as Bering Sea Water (e.g. Pisareva et al., 2015). These water 
https://doi.org/10.5194/os-2021-43

Preprint. Discussion started: 25 May 2021

masses largely take different paths in the Chukchi Sea before entering the deep central Arctic Ocean (Brugler et al., 2014)

(Fig. 1b), but mixing between these and other waters, like the water of the Siberian Coastal Current (SCC) occur (e.g.

70 Weingartner et al., 1999). In general, Alaskan Coastal Water follows the coast towards Barrow Canyon, while Bering Summer Water (also known as Bering Sea Water) splits into two branches, with one that flows through the central channel over Hanna Shoal, and one that takes a more westerly path and leaves through Herald Canyon. Part of the latter also flows into the East Siberian Sea through Long Strait. These three water masses have different salinities and nutrient concentrations (Walsh et al., 1989), where Anadyr Water is the saltiest and also has the highest nutrient concentration. Anadyr Water tends to be found on

75 the western side of Bering Strait and flows through Long Strait.

Water flowing from the Pacific Ocean into the Arctic Ocean affects the hydrography as well as the ecosystems, both in the neighboring shelf seas and the Beaufort Gyre of the Canada Basin. In this contribution, the pathways of Pacific Ocean water in the western Chukchi Sea, as well as its interaction with the waters of the eastern East Siberian Sea, are investigated based

80 on both observations and numerical modelling. The resulting volume transport is used to assess the supply of nutrients to the Arctic Ocean through Herald Canyon.

\section{Methods}

\subsection{Data}

The data presented were collected during two cruises, the International Siberian Shelf Study in 2008 (ISSS-08) and the Swedish

85 - Russian - US Arctic Ocean Investigation of Climate-Cryosphere-Carbon Interactions (SWERUS-C3) expedition in 2014, see Fig. $1 \mathrm{~b}$ for station locations. The ISSS-08 cruise was conducted along the Siberian shelf seas using the Russian vessel Yacob Smirnitskyi and started on 15 August 2008 in Kirkenes, Norway, and ended in the same port on 26 September. The SWERUS-C3 expedition was conducted along the continental shelf break of northern Siberia. The expedition consisted of two legs with icebreaker Oden. Leg 1 started on 5 July 2014 in Tromsø, Norway, and followed the Siberian continental shelf to end in Barrow, Alaska, 21 August. Leg 2 focused on the continental shelf break, slope and the adjacent deep Arctic Ocean basin and ended in Tromsø on 3 October. The Herald Canyon stations were occupied during 6-8 September in 2008 and during 24-26 August in 2014. To assess the atmospheric and sea ice conditions during and preceding the two cruises we used daily NSIDC SMMR sea ice concentrations (Cavalieri et al., 1996) at $25 \mathrm{~km}$ resolution and daily $10 \mathrm{~m}$ wind velocities and monthly surface heat fluxes from the NCEP North American Regional Analysis (NARR; Mesinger et al., 2006) at $32 \mathrm{~km}$ resolution.

During both cruises CTD observations were made using a Seabird 911+ CTD equipped with dual Seabird SBE3 temperature, SBE4C conductivity and SBE43 oxygen sensors. Water samples were collected from a CTD/rosette system equipped with 12 and 24 bottles of Niskin type, respectively, each having a volume of $7 \mathrm{~L}$. The salinity data was calibrated against water samples 
https://doi.org/10.5194/os-2021-43

Preprint. Discussion started: 25 May 2021

analyzed onboard using a laboratory salinometer (Autosal, Guildline Instruments). The calibration and processing procedures
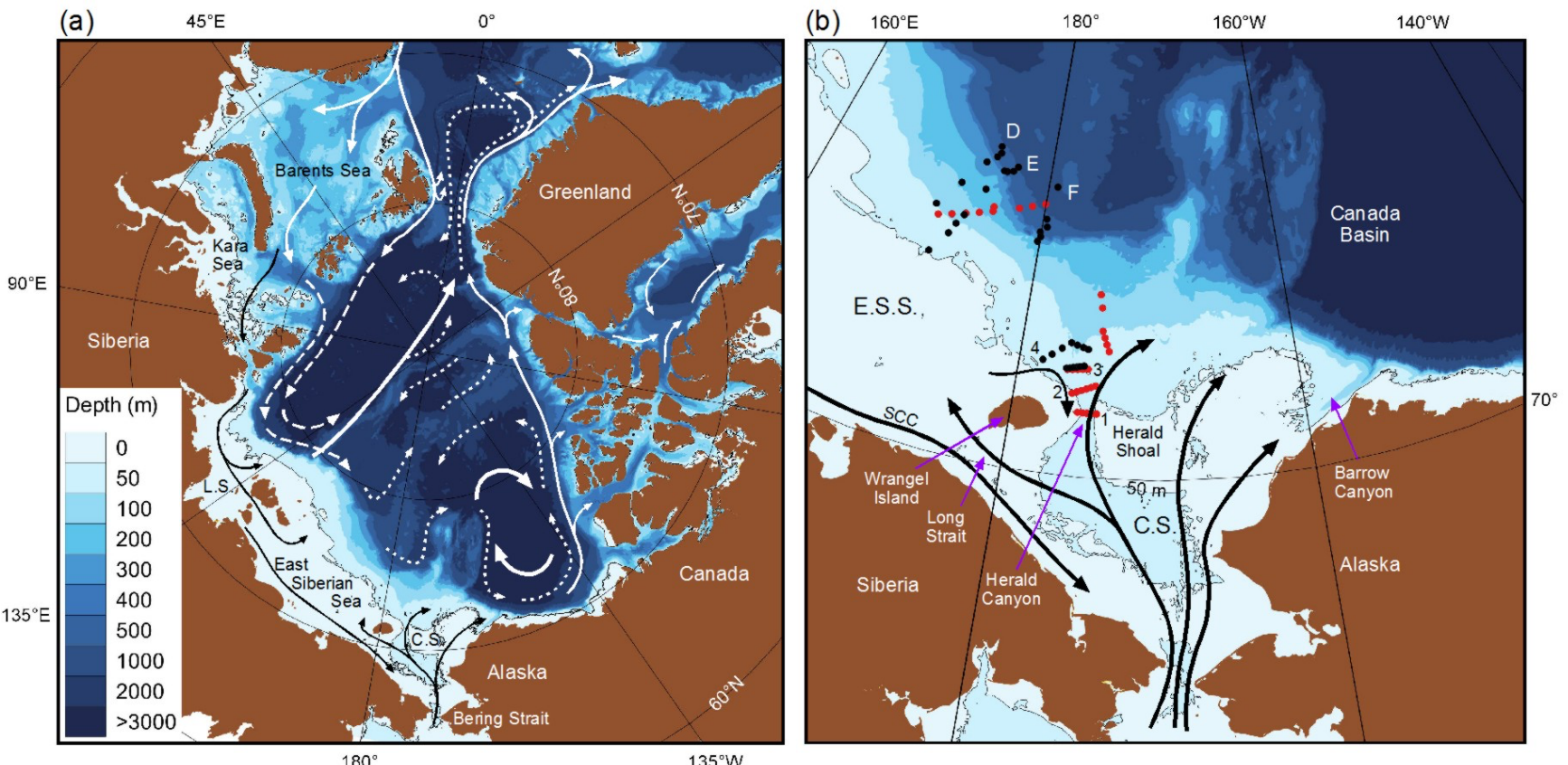

Figure 1: Map of the Arctic Ocean (a) with the mean schematic oceanic circulation illustrated by solid arrow for surface currents, interrupted arrows for intermediate currents, and dotted arrows for deep currents. In (b) a close up of the eastern East Siberian Sea (E.S.S.) and Chukchi Seas (C.S.), with stations noted from the ISSS-08 (red dots) and SWERUS-C3 (black dots). Herald Canyon sections are labelled with 1 to 4 and the continental slope sections labelled D, E, and F. SCC denotes the Siberian Coastal Current. Bathymetry is from the International Bathymetric Chart of the Arctic Ocean (IBCAO) Version 4.0 (Jakobsson et al. 2020). Please note black dots overlying red ones in section 3.

\subsubsection{Current velocities and transports}

Two 300 MHz RDI Workhorse Acoustic Doppler Current Profilers (ADCP) were mounted on the CTD rosette during the

SWERUS-C3 cruise as an upward and downward looking pair. The Lowered ADCP (LADCP) data was processed with the Lamont-Doherty Earth Observatory software package (Thurnherr et al., 2010). The velocities were de-tided (removing the tidal component) using the Arctic Ocean tidal model AOTIM (Padman and Erofeeva, 2004) with tidal velocities of 2-4 $\mathrm{cm} \mathrm{s}^{-1}$ in Herald Canyon, which is much smaller than the residual current velocities. The vertical resolution of the LADCP data is 4 $\mathrm{m}$ and the velocities were interpolated onto the $1 \mathrm{~m}$ resolution of the CTD data for the volume transport calculations.

Geostrophic shear velocities for both cruises were computed from the CTD data using the Gibbs-SeaWater Oceanographic Toolbox (McDougall and Barker, 2011). They were then interpolated onto the CTD stations and the bottom triangles filled assuming constant shear. To calculate absolute geostrophic velocities, we assured that the vertical mean of the geostrophic 
https://doi.org/10.5194/os-2021-43

Preprint. Discussion started: 25 May 2021

(c) Author(s) 2021. CC BY 4.0 License.

shear was zero and referenced to the vertical mean LADCP velocity. For the two outermost stations of each section, we used the LADCP cross-section velocities.

No LADCP data are available for ISSS-08. Instead, we exploited the fact that wind conditions were very calm over the days of the ISSS-08 survey with wind speeds below $2.7 \mathrm{~m} / \mathrm{s}$ during this period (Fig. S1). Consequently, the ship's drift was predominantly due to surface currents. An estimate of the surface currents was obtained from the ship's GPS positions during the period over which she was drifting freely at each station. The resulting ocean surface velocities were also de-tided using AOTIM (Padman and Erofeeva, 2004). The surface current speeds obtained for ISSS-08 (0.1-0.27 $\mathrm{m} \mathrm{s}^{-1}$ for section 3, which is common to both surveys) are consistent in magnitude with the SWERUS-C3 LADCP velocities (0.03-0.25 $\mathrm{m} \mathrm{s}^{-1}$ for surface speeds, $0.05-0.27 \mathrm{~m} \mathrm{~s}^{-1}$ for vertical mean speeds for section 3). Figure 2 shows that the ISSS-08 surface velocities for section 3 have the same pattern of northward flow in the eastern and southward flow in the western part of Herald Canyon also present 130 in the 2014 SWERUS-C3 LADCP observations, as well as in the 2004 and 2009 observations presented in Linders et al. (2017). This gives us confidence in using the surface currents derived from the ship's drift to reference our geostrophic shear velocities. 


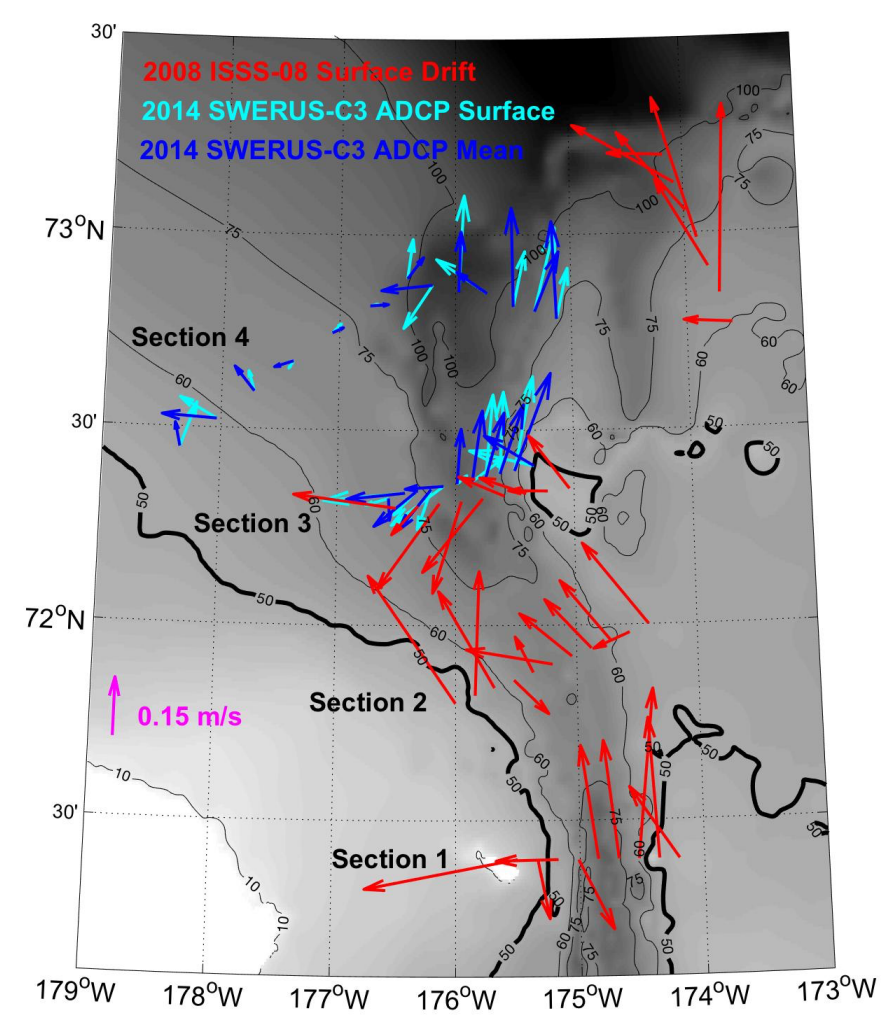

Figure 2: Circulation pattern in Herald Canyon and reference velocities for the geostrophic shear velocities. Shown are 2014 SWERUS-C3 vertical mean LADCP velocities (blue arrows), 2014 SWERUS-C3 surface LADCP velocities (cyan arrows), and 2008 140 ISSS-08 surface velocities from ship drift and navigation data (red arrows). Bathymetry (gray-scale shading and black contours) is from the International Bathymetric Chart of the Arctic Ocean (IBCAO, Jakobsson et al., 2012).

To evaluate the robustness of the flow pattern referencing to either vertical mean or surface currents, we referenced the geostrophic shear for the SWERUS-C3 sections to both surface and vertical mean LADCP velocities (Fig. 2) and compared

145 them to the original ADCP velocities during the 2014 study. Figure S2 shows that the general features of the cross-section velocity fields are consistent between all three, in particular the location of the boundary between northward and southward flow. Volume transports computed using the different velocity fields agree closely (Fig. S3).

\subsubsection{Biogeochemistry}

All chemical measurements discussed in this contribution were performed onboard the research vessels. The samples were

150 stored cold and dark before determination, which was carried out within a day of sampling. In 2008 nutrients (phosphate, nitrate, and silicate) were determined by a SMARTCHEM 200 discrete analyzer (Westco Scientific Instruments/Unity Scientific). The samples were filtered before analysis and evaluated by a 6 to 8 -points calibration curve, precision being $\sim 1 \%$. In 2014 the same nutrients were measured onboard using a four-channel continuous flow analyzer (QuAAtro system, SEAL 
https://doi.org/10.5194/os-2021-43

Preprint. Discussion started: 25 May 2021

Analytical) giving a precision between 1 and 3\%. The quality was assured by automatic drift control using certified reference materials (CRM) solutions prepared from commercial ampoules (QC RW1, Batch VKI-9-3-0702), except for silicate where no CRM is available. During both cruises oxygen was determined using an automatic Winkler titration system, giving a precision of $\sim 1 \mu \mathrm{mol} \mathrm{kg}{ }^{-1}$. Dissolved Inorganic Carbon (DIC) was determined by a coulometric titration method based on Johnson et al. (1987), having a precision of $\sim 2 \mu \mathrm{mol} \mathrm{kg}{ }^{-1}$, with the accuracy set by calibration against CRM, supplied by A. Dickson, Scripps Institution of Oceanography (USA).

The chemical variables on both cruises were sampled every second station at 8-10 depths per station. To compute transports of nutrients and dissolved inorganic carbon, we interpolated the bottle sample concentrations first vertically onto the $1 \mathrm{~m}$ resolution of the CTD data and then horizontally onto the intermediate stations. The achieved fields where then used to compute the average concentrations of the different water masses, as identified by their $\mathrm{T} / \mathrm{S}$ properties.

\subsection{Model description}

We utilize results from the Regional Arctic System Model (RASM) to assess the circulation and water mass characteristics in the Chukchi Sea. RASM has been developed over the past decade and each component, as well as the fully-coupled system, has been thoroughly evaluated (Brunke et al., 2018; Cassano et al., 2017; Clement Kinney et al., 2020; DuVivier et al., 2016; Hamman et al., 2016, 2017; Jin et al., 2018; Roberts et al., 2015; Roberts et al., 2018). RASM is a high-resolution atmosphereice-ocean-land regional model with a domain encompassing the entire marine cryosphere of the Northern Hemisphere, including the major inflow and outflow pathways, with extensions into the North Pacific and Atlantic oceans. RASM has been developed in order to represent Arctic relevant processes with coupling among model components at high spatio-temporal resolution. It is a fully coupled regional Earth system model with components including, atmosphere, ocean, sea ice, marine biogeochemistry, land hydrology, and a river routing scheme. All the components are coupled using the flux coupler of Craig et al. (2012). The RASM domain includes all sea-ice covered oceans in the Northern Hemisphere, Arctic river drainage, and large-scale atmospheric weather patterns. The components of RASM are the Weather Research and Forecasting (WRF) atmosphere model, the Variable Infiltration Capacity (VIC) land hydrology model, and the Los Alamos National Laboratory (LANL) Parallel Ocean Program (POP) and Sea Ice (CICE) Models. The model horizontal resolution is $50 \mathrm{~km}$ for WRF and VIC, and either $1 / 12^{\circ}(9 \mathrm{~km})$ or $1 / 48^{\circ}(2 \mathrm{~km})$ for POP (ocean) and CICE (sea ice).

\section{Results}

In this study we consider the dominating water masses of the Chukchi Sea: Bering Summer Water (BSW), Alaskan Coastal Water (ACW), Siberian Coastal Water (SCW), Winter Water (WW), Summer Water (SW), Melt Water (MW), and Atlantic Water (AW). The temperature and salinity definitions of these water masses follow Linders et al. (2017) and are shown in the 
https://doi.org/10.5194/os-2021-43

Preprint. Discussion started: 25 May 2021

(c) Author(s) 2021. CC BY 4.0 License.

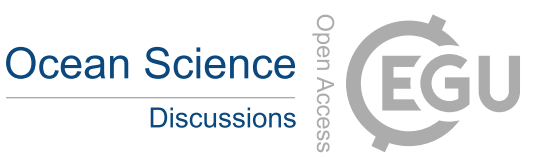

(c) (1)

temperature-salinity (T-S) diagrams in Fig. 3. We focus our analysis on the WW and BSW, as they carry the highest nutrient

185 concentrations, as illustrated by silicate in Fig. 3, and contribute to the halocline of the deep Arctic Ocean. We define Winter Water (WW) as water with a temperature less than $-1^{\circ} \mathrm{C}$ and salinity above 31 . Bering Summer Water (BSW) is warmer than WW with a maximum temperature of $3{ }^{\circ} \mathrm{C}$ and has a salinity of 30-33.3. 
a)

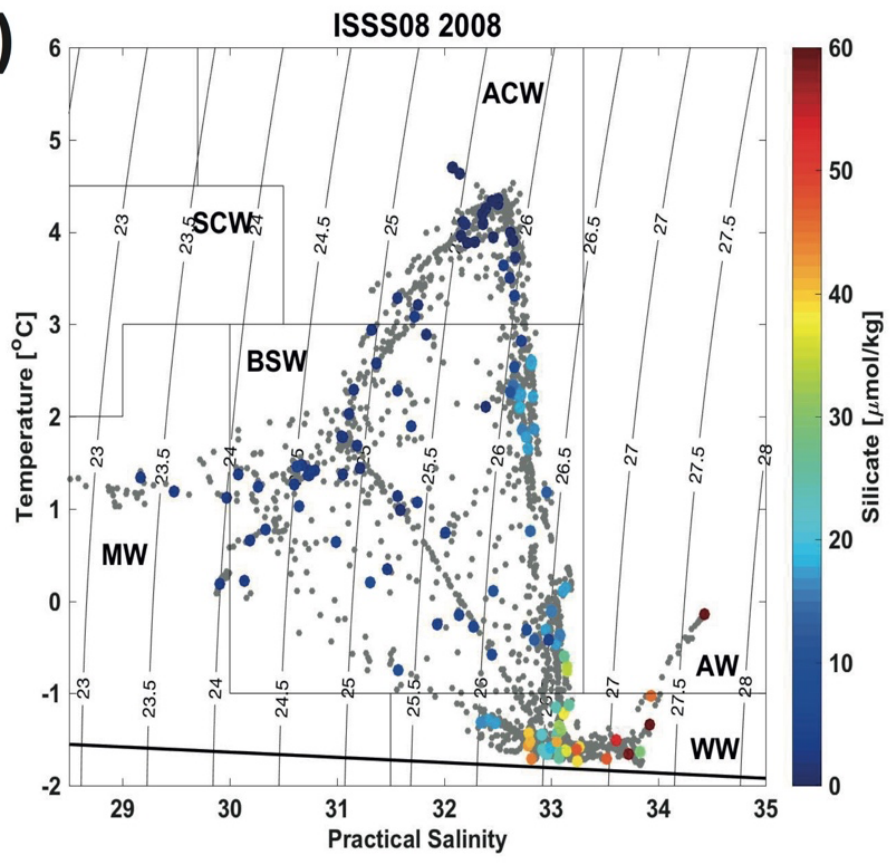

b)

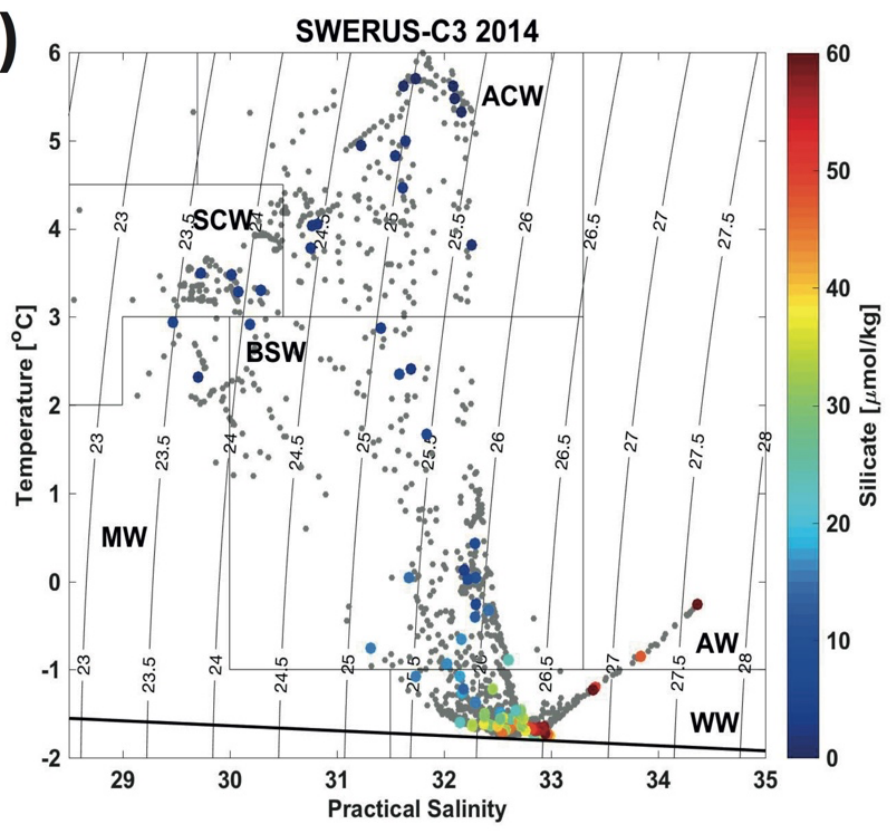

190 Figure 3: Temperature-salinity diagrams for sections 1-4 in Herald Canyon (section locations shown in Fig. 1b) for (a) 2008 and (b) 2014. Gray dots are the CTD data at $1 \mathrm{~dB}$ depth resolution, coloured dots are from the bottle data colour-coded by silicate concentration. Water masses are defined following Linders et al. (2017): WW = Winter Water, MW $=$ melt water, BSW $=$ Bering Summer Water, AW = Atlantic Water, SCW = Siberian Coastal Water, ACW = Alaskan Coastal Water. The bold black line marks the surface freezing point. 
https://doi.org/10.5194/os-2021-43

Preprint. Discussion started: 25 May 2021

(c) Author(s) 2021. CC BY 4.0 License.

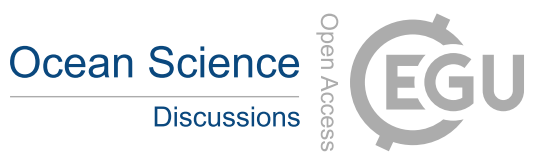

195

\subsection{Observations of hydrography and circulation}

Section 3, at about $72^{\circ} 20^{\prime} \mathrm{N}$ in the northern part of Herald Canyon (Figs. $1 \mathrm{~b}$ and 2), was occupied both in the beginning of September 2008 and the end of August 2014 and was used to compare the water mass characteristics, distribution, and circulation pattern in the two years (Fig. 4). In $2008 \mathrm{WW}$ dominates the western part of the canyon and BSW its eastern part

200 (Fig. 4e), while WW extends further east in the canyon in 2014 (Fig. 4f). Some of the shallow water with BSW characteristics in the western part of the canyon in both years is probably of local origin when surface water mixes with the underlying WW. 
a)

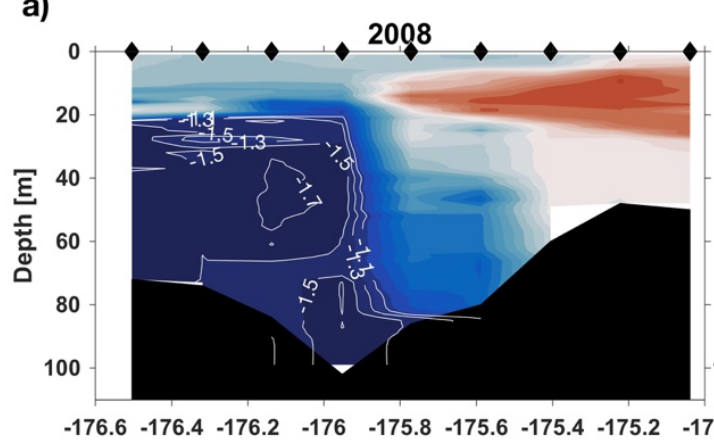

b)

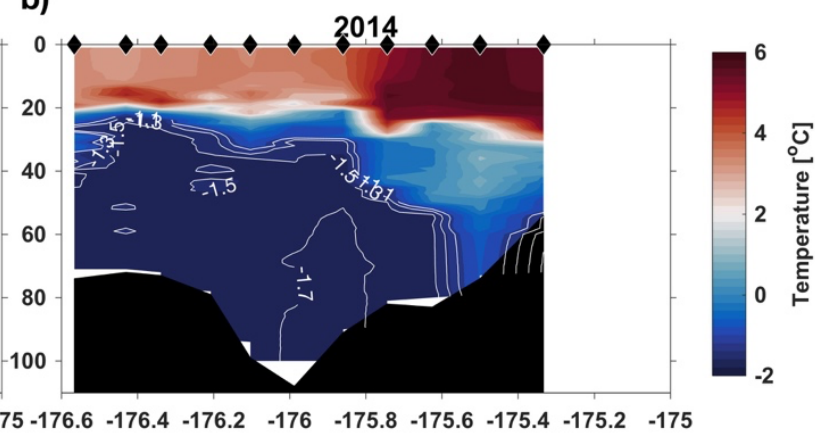

c)

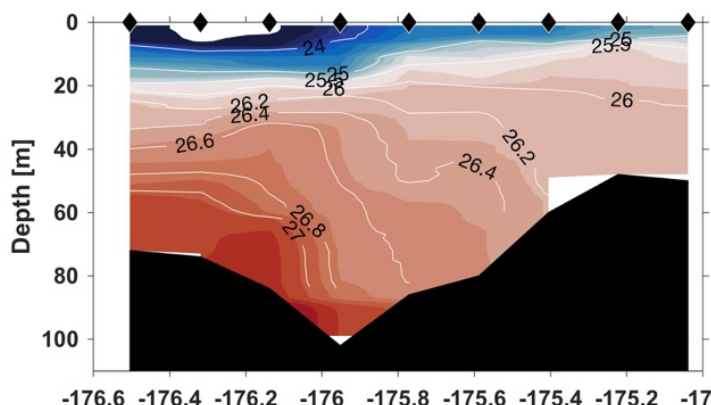

d)

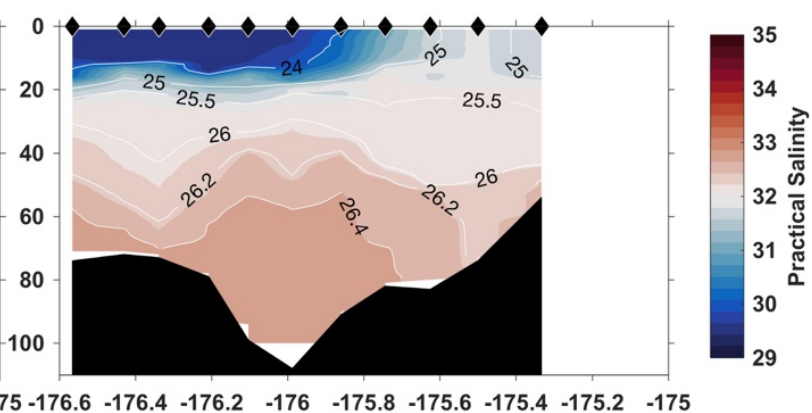

e)

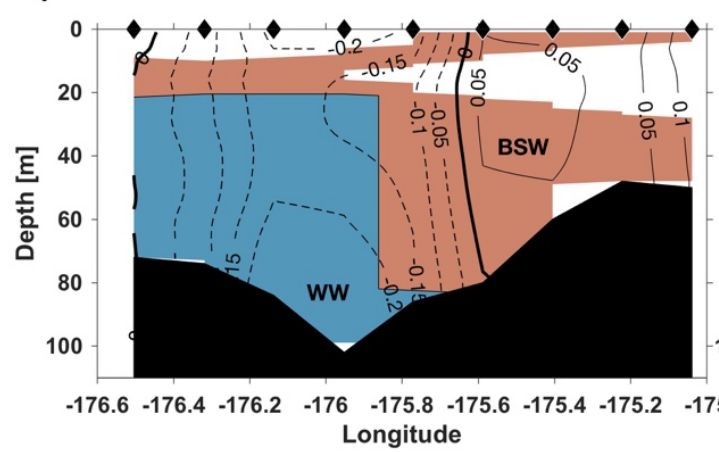

f)

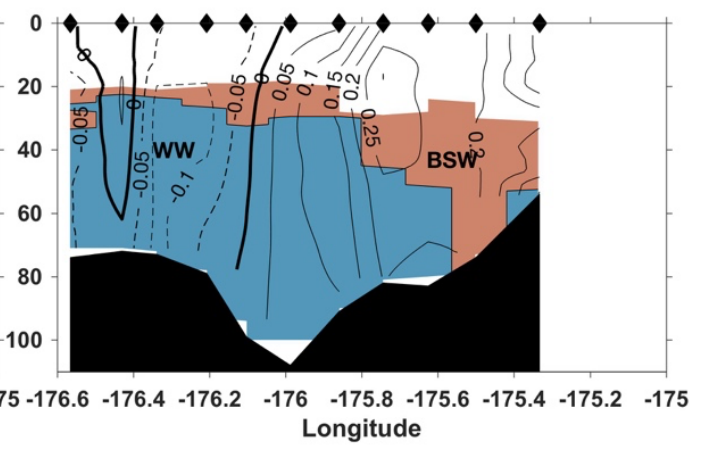

205 Figure 4: Temperature (a and b), practical salinity (c and d) for section 3 at approx. $7^{\circ}{ }^{2} 0^{\prime} \mathbf{N}$ (Fig. 1 b and Fig.2) in 2008 (a, c, e) and $2014(\mathrm{~b}, \mathrm{~d}, \mathrm{f})$. e) and f) show the spatial distribution of Winter Water (WW, blue) and Bering Summer Water (BSW, red) as defined following Linders et al. (2017) (see also Fig. 3) together with cross-section velocities $\left(\mathrm{m} \mathrm{s}^{-1}\right)$ computed as described in section 2.2. Solid contours denote northward (positive) velocities, while dashed ones represent southward (negative) ones. The white contours in a and $b$ show the temperature structure in the $\mathrm{WW}$. Those in $\mathrm{c}$ and $\mathrm{d}$ are potential density $\sigma_{0}\left(\mathrm{~kg} \mathrm{~m}^{-3}\right)$.

When comparing the T-S characteristics of the water masses in Herald Canyon in the 2008 and 2014 observations (Fig. 3), it is apparent that the cold WW had significantly lower salinities in 2014 than in 2008 . The mean WW salinity in 2014 was 0.56 lower than in 2008 (Table 1). The freshening in the BSW is weaker ( 0.09 between 2008 and 2014), and its mean temperature shows a decrease of $0.84^{\circ} \mathrm{C}$ from 2008 to 2014 (Table 1). This temperature change can partly be explained by the fact that the 2152008 section extends further east onto Herald Shoal (Fig. 1) capturing a larger part of the BSW flow and partly by the fact that 
https://doi.org/10.5194/os-2021-43

Preprint. Discussion started: 25 May 2021

(c) Author(s) 2021. CC BY 4.0 License.

the freshening of the WW in 2014 has weakened the density front between BSW and WW leading to enhanced exchange and mixing (Fig. 4c and d).

Table 1: Mean properties of the Winter Water (WW) and Bering Summer Water (BSW) observed in 2008 and 2014.

\begin{tabular}{|c|c|c|c|c|c|c|}
\hline Water mass & Salinity & Temp & $\begin{array}{c}\mathrm{PO}_{4} \\
\left(\mu \mathrm{mol} \mathrm{L} \mathbf{L}^{-1}\right)\end{array}$ & $\begin{array}{c}\mathrm{NO}_{3} \\
\left(\mu \mathrm{mol} \mathrm{L} \mathbf{L}^{-1}\right)\end{array}$ & $\begin{array}{c}\mathrm{SiO}_{2} \\
\left(\mu \mathrm{mol} \mathrm{L}{ }^{-1}\right)\end{array}$ & $\begin{array}{c}\text { DIC } \\
\left(\mu \mathrm{mol} \mathrm{kg}{ }^{-1}\right)\end{array}$ \\
\hline WW-2008 & 33.22 & -1.55 & 2.46 & 13.5 & 39.1 & 2243 \\
\hline WW-2014 & 32.66 & -1.61 & 1.77 & 11.7 & 40.7 & 2224 \\
\hline BSW-2008 & 32.25 & 1.12 & 1.49 & 5.1 & 11.3 & 2084 \\
\hline BSW-2014 & 32.16 & 0.28 & 1.04 & 4.2 & 10.0 & 2107 \\
\hline
\end{tabular}

220 Net total volume transports across section 3 of $0.279 \mathrm{~Sv}\left(10^{6} \mathrm{~m}^{3} \mathrm{~s}^{-1}\right)$ southward in 2008 and $0.240 \mathrm{~Sv}$ northward in 2014 (Table 2 ) indicate that flow pattern and transport in this part of Herald Canyon are highly variable. Flow in the canyon at section 3 is pre-dominantly barotropic, southward in the western part of the canyon and northward on its eastern flank (Fig. 4e and f and Fig 5). Both surface and vertical mean ADCP velocities in 2014 and surface velocities from the ship's drift in 2008 show this pattern with stronger southward flow in the western canyon in 2008 that extends eastward to $175.6^{\circ} \mathrm{W}$ (Fig. 4e). This results in $0.231 \mathrm{~Sv}$ of southward WW transport across section 3 in 2008 with a negligible northward component (Table 2). BSW recirculates southward in the center of the canyon with a transport of $0.106 \mathrm{~Sv}$ southward, and a northward transport of 0.052 Sv at the eastern end of the section (Fig. 4e). In 2014, a westward shift in the boundary between northward and southward flow and the eastward extension of WW (Fig. 4f) results in a weaker southward WW transport of $0.073 \mathrm{~Sv}$ and a northward WW transport of $0.127 \mathrm{~Sv}$ in the central canyon that contains the core of the coldest WW with temperatures $<-1.7^{\circ} \mathrm{C}$ (Fig. $4 \mathrm{~b}$ and f). BSW flows predominantly north with a net transport of $0.118 \mathrm{~Sv}$ (Table 2). 
https://doi.org/10.5194/os-2021-43

Preprint. Discussion started: 25 May 2021

Table 2: Volume transports computed from observations according to section 2.2 for the sections in Herald Canyon. All transports are in $\mathrm{Sv}\left(10^{6} \mathrm{~m}^{3} \mathrm{~s}^{-1}\right)$. Negative values denote southward transports, positive northward ones. Note that the values for the total volume transport are larger than the sum of the WW and BSW transports due to the presence of other water masses in Herald

245 Canyon (Fig. 3).

\begin{tabular}{|c|c|c|c|c|c|}
\hline Section & 1 & 2 & 3 & 3 & 4 \\
\hline Latitude & $71^{\circ} 25^{\prime} \mathrm{N}$ & $71^{\circ} 55^{\prime} \mathrm{N}$ & $72^{\circ} 20^{\prime} \mathrm{N}$ & $72^{\circ} 25^{\prime} \mathrm{N}$ & $72^{\circ} 40^{\prime} \mathrm{N}$ \\
\hline Year & 2008 & 2008 & 2008 & 2014 & 2014 \\
\hline Net Total & 0.474 & 0.329 & -0.279 & 0.240 & 0.618 \\
\hline Total North & 0.572 & 0.390 & 0.082 & 0.357 & 0.745 \\
\hline Total South & -0.098 & -0.061 & -0.361 & -0.117 & -0.127 \\
\hline Net WW & -0.019 & 0.191 & -0.231 & 0.054 & 0.349 \\
\hline WW North & 0.004 & 0.198 & 0.000 & 0.127 & 0.445 \\
\hline WW South & -0.023 & -0.007 & -0.231 & -0.073 & -0.096 \\
\hline Net BSW & 0.293 & 0.051 & -0.054 & 0.118 & 0.082 \\
\hline BSW North & 0.363 & 0.093 & 0.052 & 0.132 & 0.089 \\
\hline BSW South & -0.070 & -0.042 & -0.106 & -0.014 & -0.007 \\
\hline
\end{tabular}

In the southern Herald Canyon in 2008, flow across sections 1 and 2 was predominantly directed northward (Fig. 5d and e) with net total volume transports of 0.474 and $0.329 \mathrm{~Sv}$, respectively (Table 2). Linders et al. (2017) present 2009 LADCP observations of northward flow across the whole canyon similar to the 2008 section 2 (Fig. 5d) suggesting that this flow pattern is not unprecedented. Consequently, section 2 has a northward WW transport of $0.198 \mathrm{~Sv}$ and little southward WW flow (0.007 Sv). At section 1, very little WW was observed and its flow was thus small. The net northward transport of $0.474 \mathrm{~Sv}$ across section 1 is dominated by a northward BSW transport of $0.363 \mathrm{~Sv}$ in the eastern part of the canyon (Fig. 5e) with a smaller southward component of $0.070 \mathrm{~Sv}$ along its western flank. The reduction of the northward flow of BSW to $0.093 \mathrm{~Sv}$ at section 2 and $0.052 \mathrm{~Sv}$ across section 3 with a re-circulation of $0.106 \mathrm{~Sv}$ in the western trough suggests there may be circulation 255 patterns in the trough that block the transport of BSW towards the Arctic Ocean. Our observations do not, however, allow us to say how often these occur or how persistent they are. 


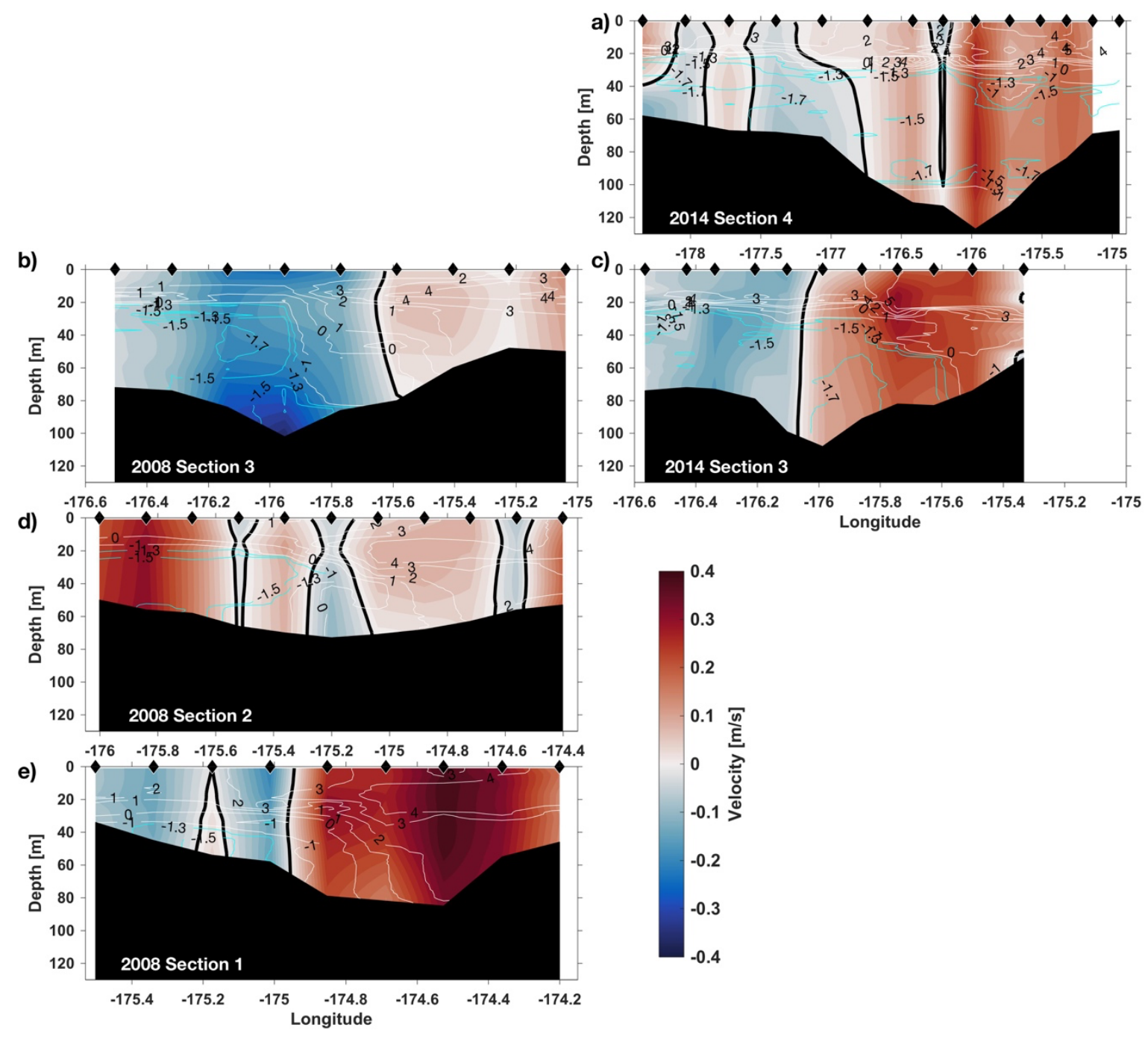

Figure 5: Cross-section velocities in 2008 for sections from north (b), (d), and (e) and in 2014 (a) and (c). Shown in all panels is geostrophic shear referenced to the cross-section component of de-tided surface velocities from ship's drift (2008) and LADCP (2014). The white contours show temperature from -1 to $8^{\circ} \mathrm{C}$ at $1^{\circ} \mathrm{C}$ intervals, the cyan ones from -1.3 to $-1.7^{\circ} \mathrm{C}$ at $0.2^{\circ} \mathrm{C}$ to highlight the temperature structure within the WW.

In 2014, 0.089 Sv of BSW flows north across the eastern part of section 4 into the Arctic Ocean (Fig. 5a and Table 2), smaller, but of a similar magnitude to the BSW transport across section 3. WW is found at depths between 20 and $100 \mathrm{~m}$ across section 4 and dominates the total transport with a northward flow of $0.445 \mathrm{~Sv}$ in the mouth of Herald Canyon and a southward transport of $0.096 \mathrm{~Sv}$ on its western flank onto the Chukchi continental shelf. Both of these WW transports contain cores with temperatures $<-1.7^{\circ} \mathrm{C}$ indicating recent winter ventilation (Fig. 5a). 
https://doi.org/10.5194/os-2021-43

Preprint. Discussion started: 25 May 2021

(c) Author(s) 2021. CC BY 4.0 License.

Our sections represent snapshots of a circulation that is predominantly barotropic in a shallow ocean area and therefore is likely strongly influenced by changes in the wind field over synoptic timescales leading to strong variability of both current pattern and strength. Furthermore, the sections do not cover the full width of Herald Canyon and thus water is also flowing outside of these sections. For this reason, we compare the observations with model results where the sections can be selected

275 in suitable ways and allow us to gain an understanding of the spatial and temporal variability of the flow over a larger area and longer timescales.

\subsection{Modelled circulation}

The numerical modelling results support the general circulation scheme of the Chukchi Sea (e.g. Brugler et al., 2014) but show 280 a more detailed picture both in time and space. Mean circulation in the upper $100 \mathrm{~m}$ (Fig. 6ab) is similar to the schematic circulation presented in Fig. 1 when averaged over a 10-year period (2006-2015). Our results show a north-westward flowing Chukchi Slope Current, similar to recent results by Leng et al. (2021), who used a combination of modelling and observations to examine this flow in detail. Limited observations in Long Strait (Woodgate et al., 2005) suggest a north-westward flow and our model results (Fig. 6) are in agreement. When we look at the circulation averaged over a summer month when observations

285 were collected (e.g. September 2008; Fig. 6cd) we see more complex circulation across the shelf, as well as eddies in the Beaufort Gyre. The circulation in August 2014 (during the second field expedition; Fig. 6ef) shows much higher speeds in the East Siberian Sea and a weaker flow around Wrangel Island than in September 2008. When comparing the 9-km model output and the $2-\mathrm{km}$ model output there is little difference in the long-term means, but at shorter time scales we tend to see higher speeds and more eddies in the 2-km simulation. 
https://doi.org/10.5194/os-2021-43

Preprint. Discussion started: 25 May 2021

(c) Author(s) 2021. CC BY 4.0 License.
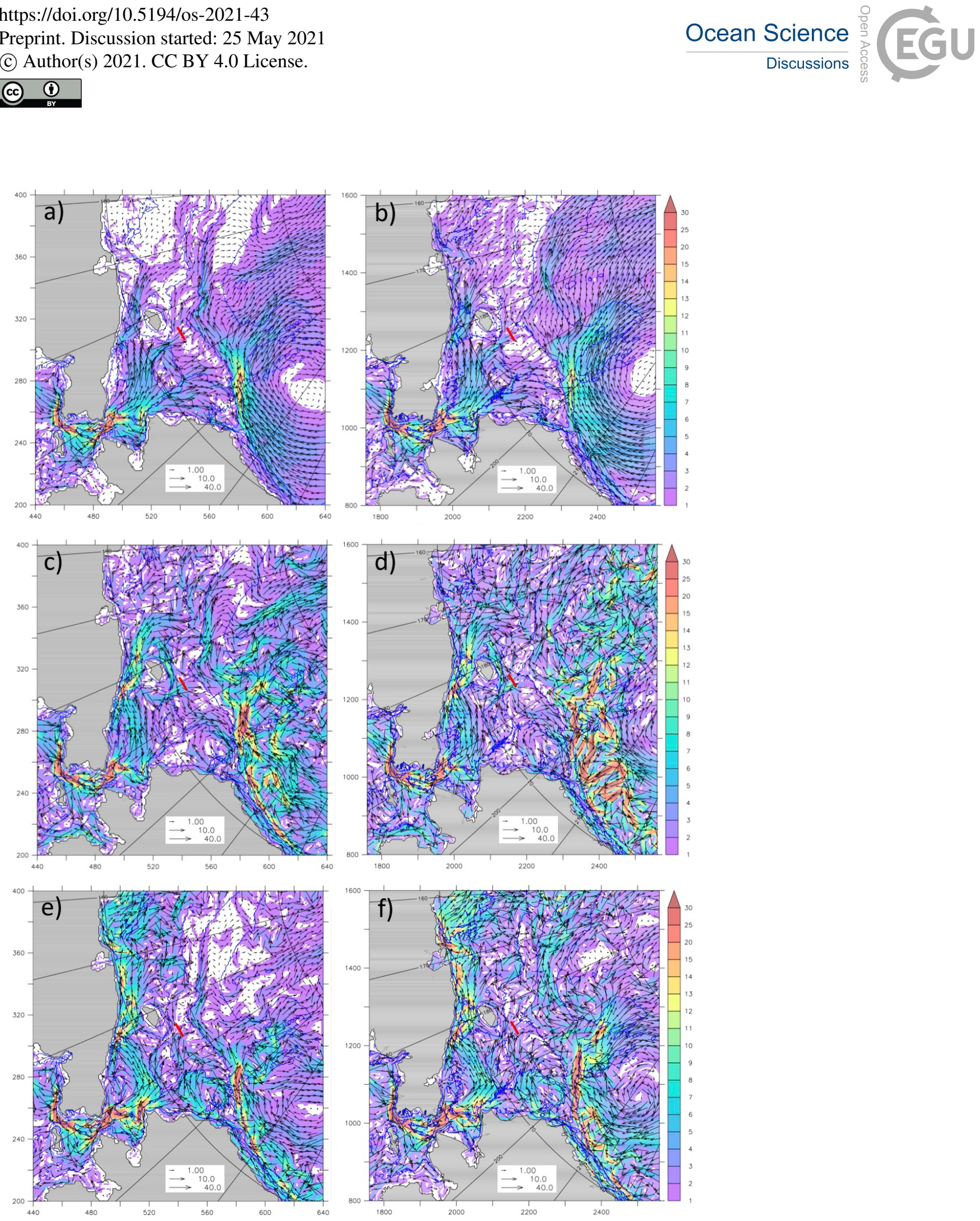

Figure 6: Upper 100m averaged speed (shading) and velocity vectors $(\mathrm{cm} / \mathrm{s})$ from model output. The left column (a, c, e) is from the $9 \mathrm{~km}$ model results and the right column $(b, d, f)$ is from the $2 \mathrm{~km}$ model results. The top row $(\mathrm{a}, \mathrm{b})$ is a 10 -year mean from $2006-$ 2015. The middle row $(c, d)$ is a mean for September 2008. The bottom row $(e, f)$ is a mean for August 2014. Every $4^{\text {th }}$ vector for the $9 \mathrm{~km}$ and every $16^{\text {th }}$ vector for the $2 \mathrm{~km}$ is shown. The red line indicates the location of section 3 discussed elsewhere. 
https://doi.org/10.5194/os-2021-43

Preprint. Discussion started: 25 May 2021

(c) Author(s) 2021. CC BY 4.0 License.

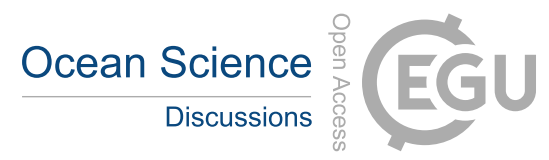

Figure 7 shows the modelled circulation zoomed in on Herald Canyon. The 10-year mean (Fig. 7ab) shows speeds of up to 10 $\mathrm{cm} / \mathrm{s}$ northward in Herald Canyon. The summer months show stronger anticyclonic flow around Wrangel Island, particularly during September 2008 (Fig. 7cd), with speeds up to $12 \mathrm{~cm} / \mathrm{s}$ north of Wrangel Island. The modelled circulation also suggests 300 that in 2014 water flowing northward in eastern Herald Canyon may have been sourced from flows across Herald Shoal (Fig. 7 c-f). This may offer an explanation for higher nutrient concentrations in the BSW in 2014 (Table 1). The largest differences between the $9-\mathrm{km}$ and $2-\mathrm{km}$ simulations are found north of the $100 \mathrm{~m}$ isobath with more complex circulation in the $2-\mathrm{km}$ simulation. 
https://doi.org/10.5194/os-2021-43

Preprint. Discussion started: 25 May 2021

(c) Author(s) 2021. CC BY 4.0 License.
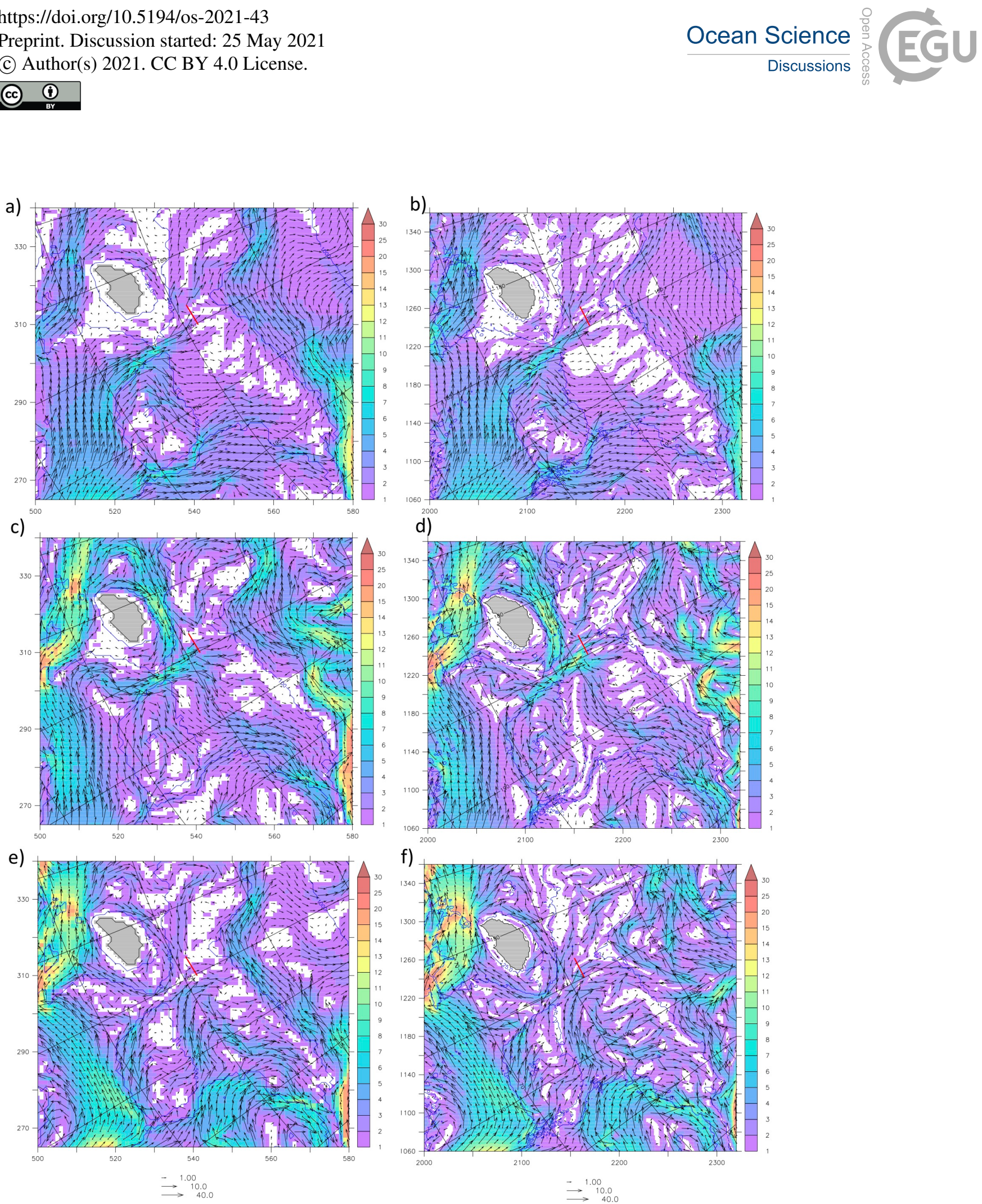

305 Figure 7: Upper 100m averaged speed (shading) and velocity vectors $(\mathrm{cm} / \mathrm{s})$ from model output. The left column (a, c, e) is from the $9 \mathrm{~km}$ model results and the right column $(\mathrm{b}, \mathrm{d}, \mathrm{f})$ is from the $2 \mathrm{~km}$ model results. The top row (a, b) is a 10 -year mean from $2006-$ 2015. The middle row $(c, d)$ is a mean for September 2008. The bottom row $(e, f)$ is a mean for August 2014. Every $2^{\text {nd }}$ vector for the $9 \mathrm{~km}$ and every $8^{\text {th }}$ vector for the $2 \mathrm{~km}$ is shown. The red line indicates the location of section 3 discussed elsewhere. 
https://doi.org/10.5194/os-2021-43

Preprint. Discussion started: 25 May 2021

(c) Author(s) 2021. CC BY 4.0 License.

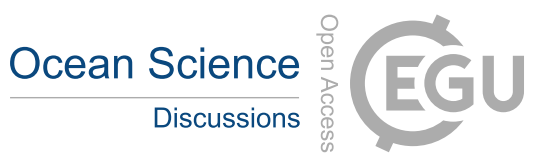

\subsection{Modelled volume flux in Herald Canyon across section 3}

310 Next, we will examine the modelled volume transport during August and September of 2008 and 2014, which encompasses the time period when observations were collected. Time series of daily mean volume transport across section 3 show a large range of variability in the model results (Fig. 8). Over the 2-month period of August-September 2008 (Fig. 8) the net volume transport ranged from -0.4 to $0.4 \mathrm{~Sv}$ (negative is southward) with a mean of $0.109 \mathrm{~Sv}$. A flow reversal occurred within a week's time between September 7 and September 14. We show vertical sections of temperature, salinity and velocity on those

315 two days for a comparison of these extremes (Fig. 9). The velocity core was $0.3 \mathrm{~m} \mathrm{~s}^{-1}$ southward on September 7 and $0.2 \mathrm{~m} \mathrm{~s}$ ${ }^{1}$ northward on September 14. The model is underestimating the temperature in the upper layers with values only as high as 2 ${ }^{\circ} \mathrm{C}$, whereas the observed temperature (Fig. 4a) reached $4{ }^{\circ} \mathrm{C}$. The upper layer salinity is slightly higher in the model results than in observations (Fig. 4c). 
https://doi.org/10.5194/os-2021-43

Preprint. Discussion started: 25 May 2021

(c) Author(s) 2021. CC BY 4.0 License.

a)

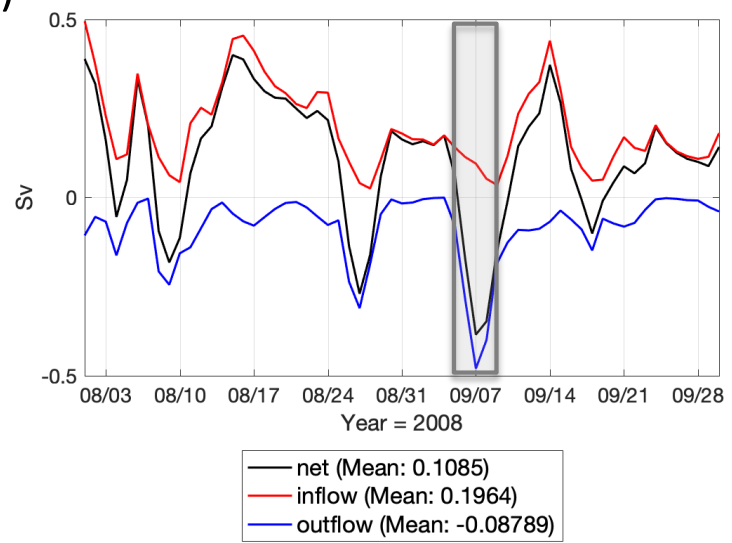

b)

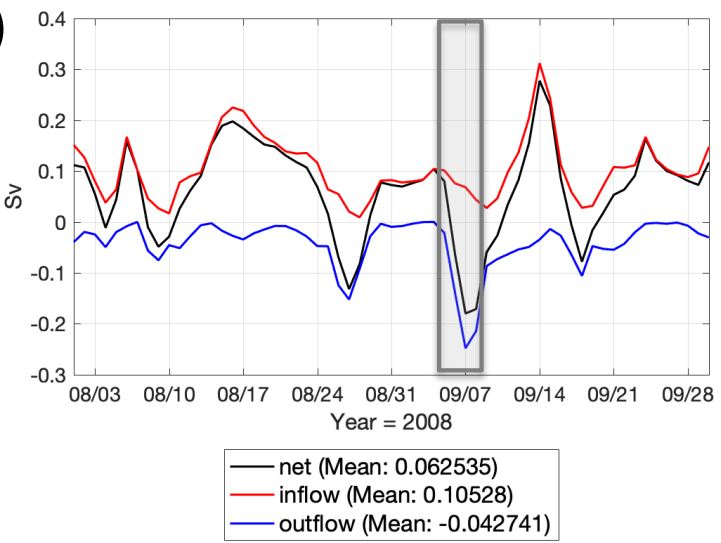

C)

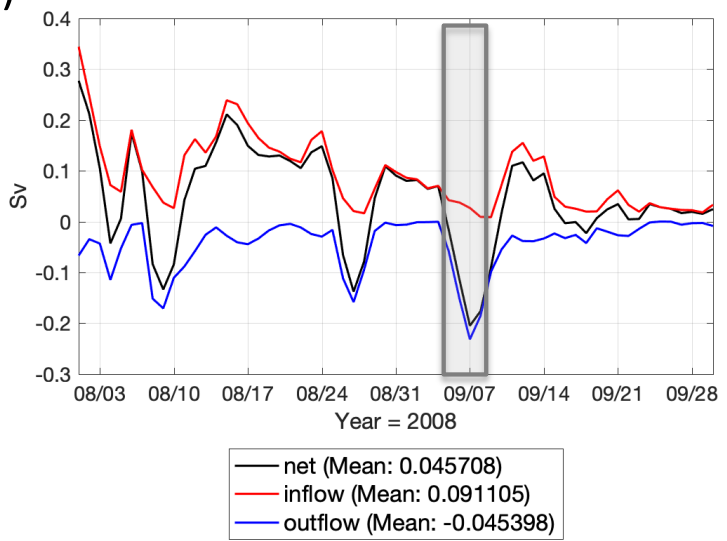

d)

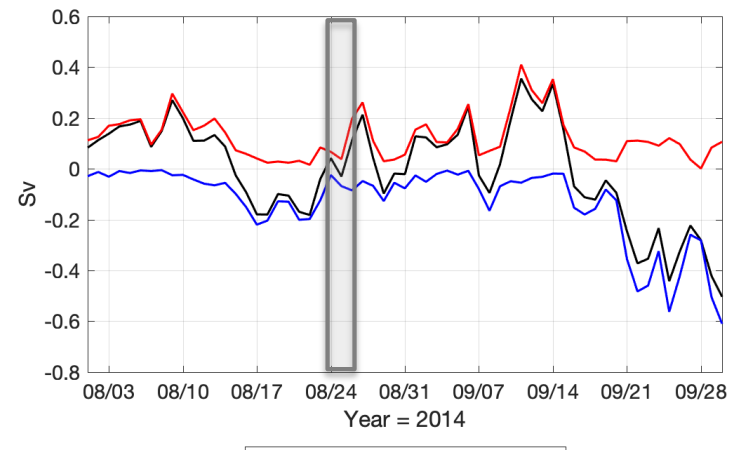

— net (Mean: -0.0071152$)$ _ outflow (Mean: -0.13153)

e)

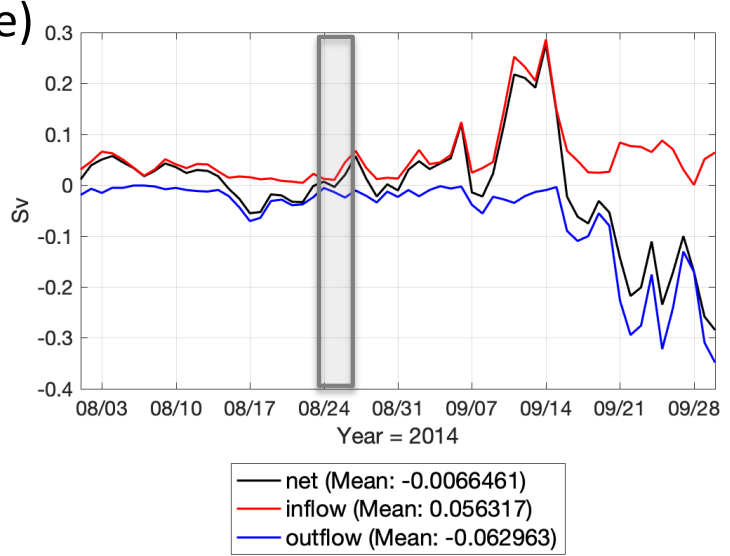

f)

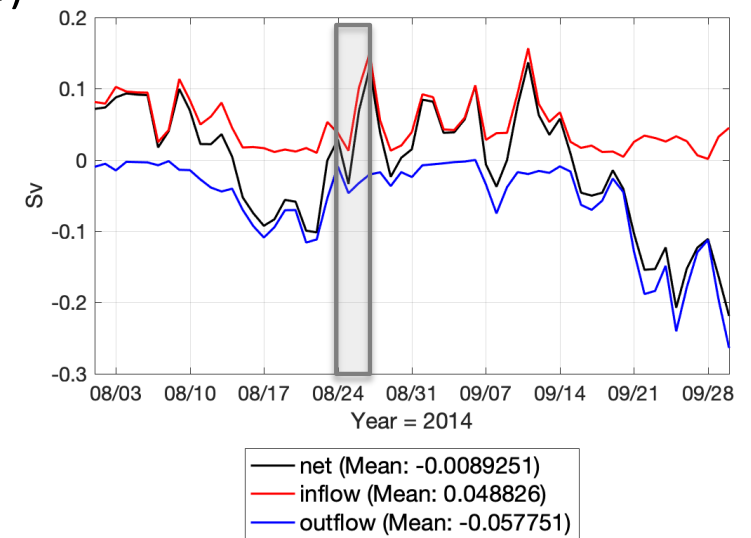

Figure 8: Daily modelled volume flux from the 9km simulation across section 3 during August-September 2008 for all water masses (a), BSW only (b), and WW only (c) and during August-September 2014 for all water masses (d), BSW only (e), and WW only (f). The gray box shows the time period during which observations were collected. Inflow values are northward and outflow is southward. 
https://doi.org/10.5194/os-2021-43

Preprint. Discussion started: 25 May 2021

(c) Author(s) 2021. CC BY 4.0 License.

Over the 2-month period of August-September 2014 the net volume transport ranged between $-0.5 \mathrm{~Sv}$ to $0.35 \mathrm{~Sv}$ with a mean of $-0.007 \mathrm{~Sv}$ (Fig. 8). There was strong, persistent southward flow during the last 10 days of September 2014, in contrast to the northward flow during the first half of September. Vertical sections of temperature show higher values (up to $3^{\circ} \mathrm{C}$ ) and lower salinity (<30) in 2014 compared to 2008 (Fig. 10).

The model results allow us to place the observations at or close to events of northward (2008; Fig. 8) and southward (2014) net volume transport of similar magnitude (Table 2). This suggests that the model is able to realistically reproduce the timing and variability of changes in circulation on synoptic timescales discussed above and shown in Figs. 9 and 10. The observed volume transports in both years are larger in magnitude and not in the same direction as the modelled August-September means. This implies that caution is required when using observations from synoptic, hydrographic sections to estimate the transport of heat, freshwater, nutrients, and carbon through Herald Canyon into the deep basin. 
https://doi.org/10.5194/os-2021-43

Preprint. Discussion started: 25 May 2021

(c) Author(s) 2021. CC BY 4.0 License.
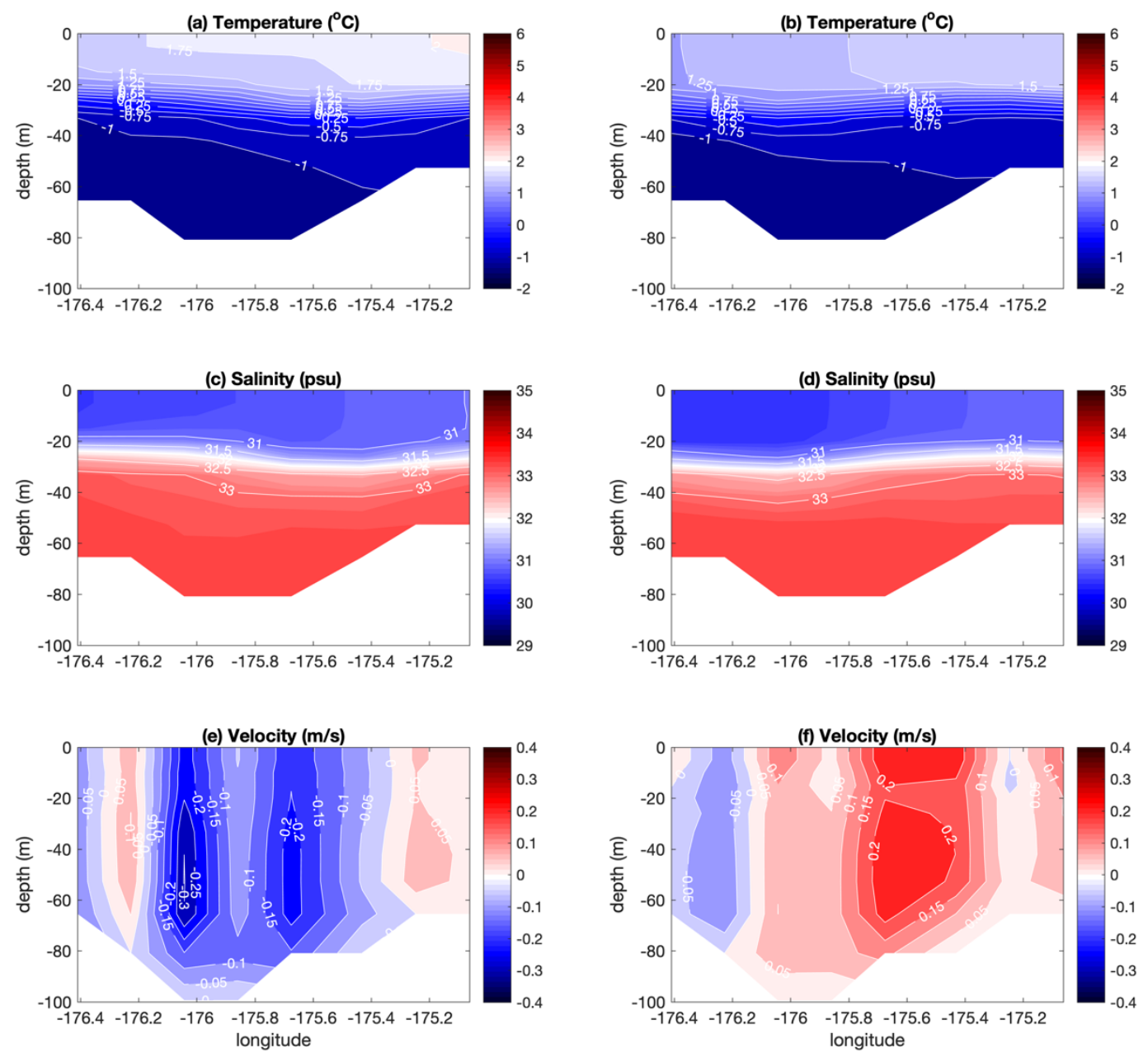

Figure 9: Modelled vertical sections from the 9km simulation across section 3 on September 7, 2008 (left) and September 14, 2008 340 (right). 
https://doi.org/10.5194/os-2021-43

Preprint. Discussion started: 25 May 2021

(c) Author(s) 2021. CC BY 4.0 License.
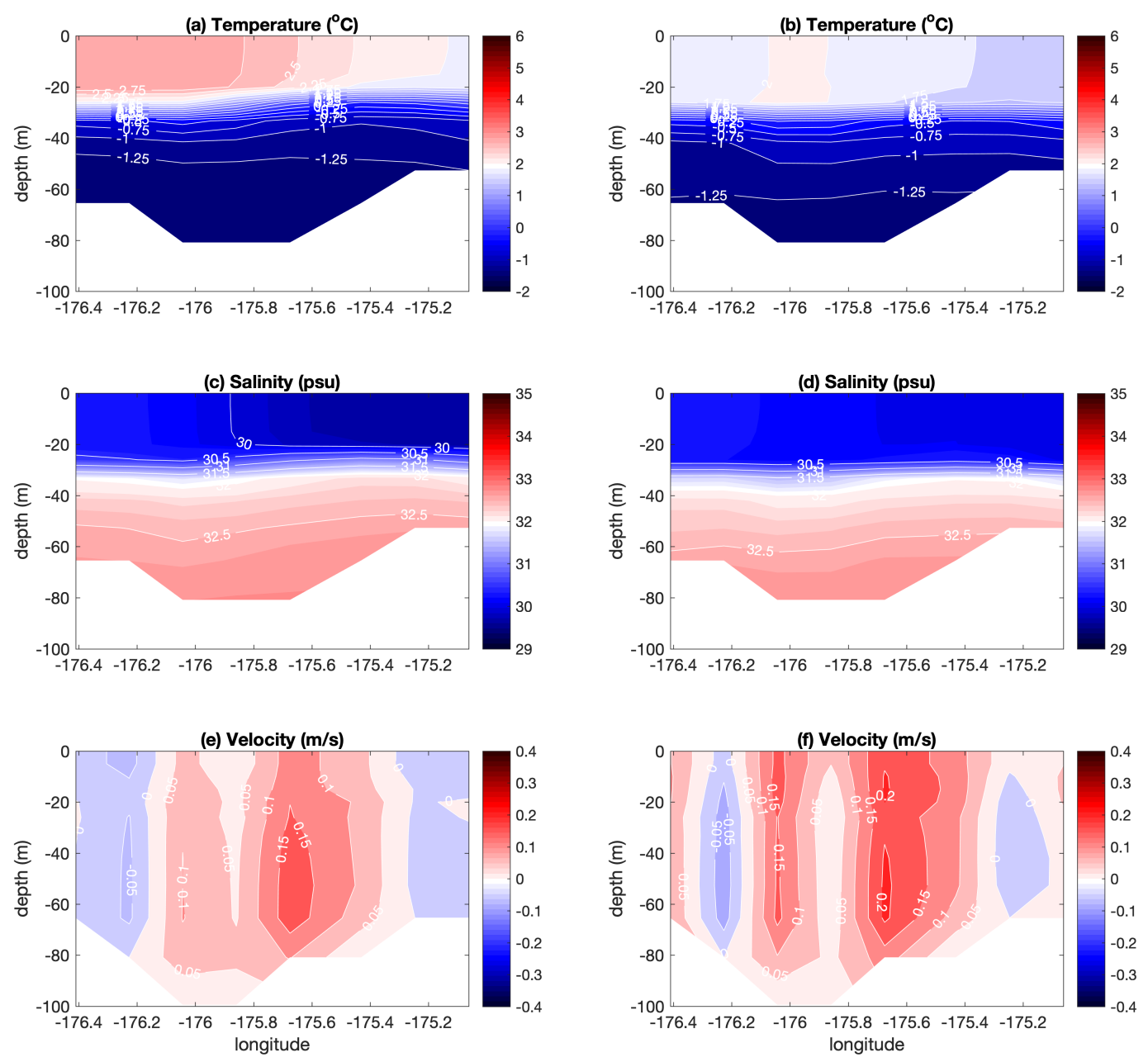

Figure 10: Modelled vertical sections from the 9km simulation across section 3 on August 27, 2014 (left) and September 11, 2014 (right).

The amount of BSW and WW is similar during the August-September time frames (Figs. 9 and 10) from the model results. For example, the northward component of the mean flow consists of $0.105 \mathrm{~Sv}$ of BSW and 0.091 Sv of WW during 2008. At the same time, the southward component of the mean flow consists of $0.043 \mathrm{~Sv}$ of BSW and $0.045 \mathrm{~Sv}$ of WW. There is more north-south variability in the time series from 2014, as compared to 2008. The lower means reflect this, with the northward component of the mean flow consisting of $0.056 \mathrm{~Sv}$ of BSW and $0.049 \mathrm{~Sv}$ of WW in 2014 and the southward component consisting of $0.063 \mathrm{~Sv}$ of BSW and $0.058 \mathrm{~Sv}$ of WW.

Figure 11 shows the modelled monthly mean volume transport across section 3 during 1980-2017. This gives a long-term perspective of the flow through Herald Canyon and indicates that the modelled mean is $0.032 \mathrm{~Sv}$ northward for all water 
https://doi.org/10.5194/os-2021-43

Preprint. Discussion started: 25 May 2021

(c) Author(s) 2021. CC BY 4.0 License.

masses combined. This includes the northward $(0.063 \mathrm{~Sv})$ and southward $(0.031 \mathrm{~Sv})$ components. BSW transport appears to be the strongest in the fall months and has been increasing in prevalence in recent years in agreement with the earlier warming seen in spring in long-term mooring observations in Bering Strait (Woodgate, 2018). The most notable feature in the time series occurred in November 2017, when the model showed a strong, persistent flow reversal in Herald Canyon with southward speeds over $30 \mathrm{~cm} / \mathrm{s}$ (Fig. S4) averaged over the upper $100 \mathrm{~m}$.

a)

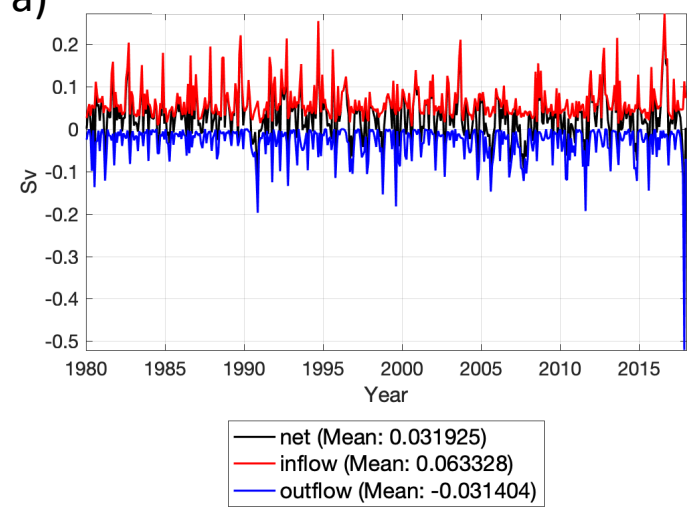

b)
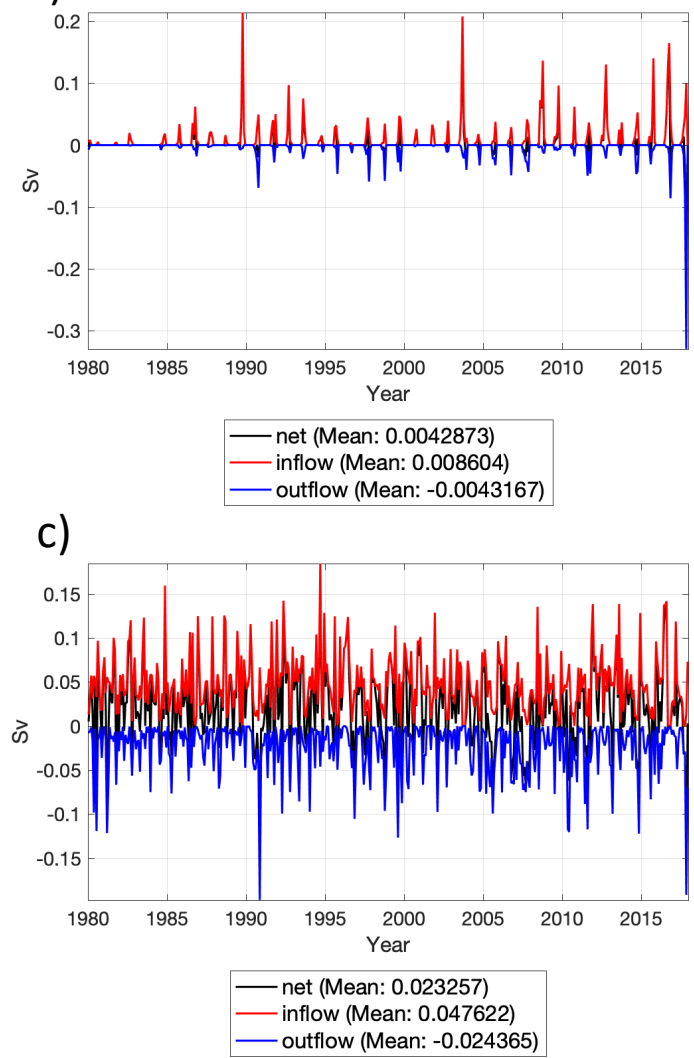

Figure 11: Monthly mean modelled volume flux (Sv) from the $9 \mathrm{~km}$ simulation across section 3 during $1980-2017$ for all water masses (a), BSW only (b), and WW only (c). Inflow values are northward and outflow is southward. 
https://doi.org/10.5194/os-2021-43

Preprint. Discussion started: 25 May 2021

(c) Author(s) 2021. CC BY 4.0 License.

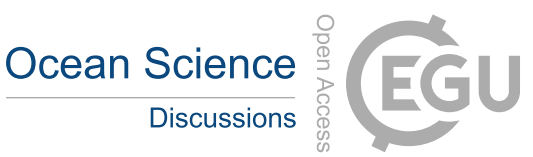

\subsection{Nutrient concentrations and transports}

The nutrient and DIC concentrations across Section 3 in 2008 and 2014 show the classical summer distribution of low values in the surface and high values in the deeper layers (Fig. 12). The dominating process for this pattern is primary production in the top $20-30 \mathrm{~m}$, followed by sedimentation and mineralization at the sediment surface where the nutrients and DIC are transported back to the bottom water. The highest concentrations of all properties are found more to the west in 2008 than in

370 2014, consistent with the distribution of WW (Fig. 4ef). Maximum concentrations of nitrate and silicate were similar in 2008 and 2014, while both phosphate and DIC were higher in 2008. 

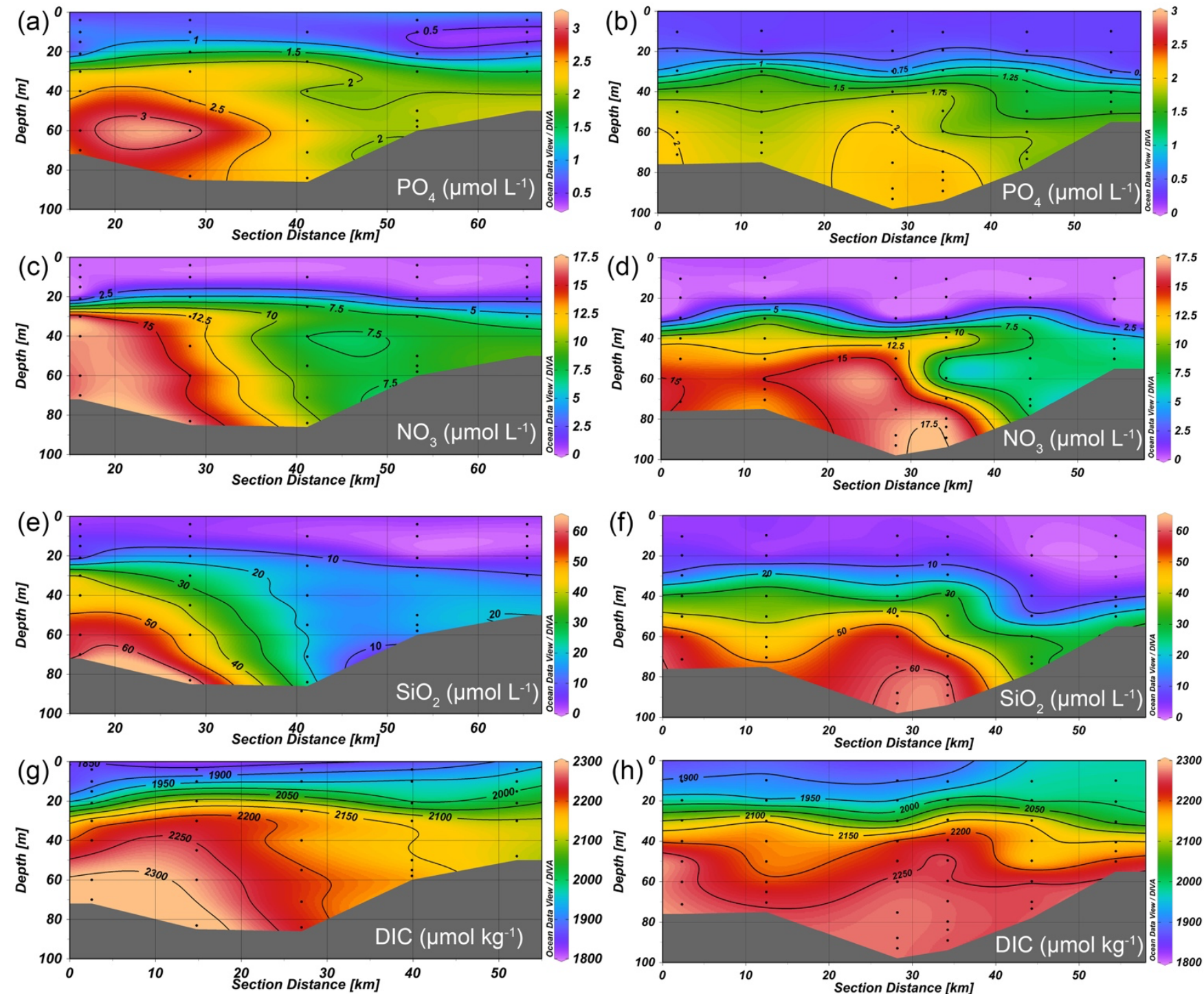

Figure 12: Observed nutrient and DIC sections at latitude about $72^{\circ} 20^{\prime} \mathrm{N}$ (noted as 3 in Fig $\left.1 \mathrm{~b}\right)$ in 2008 (a, c, e, g) and 2014 (b, d, f,

To compute the transports, the mean concentrations of nutrients and DIC were calculated by first interpolating the bottle sample concentrations vertically onto the T-S points from the CTD reading of each station where they were available and, subsequently, horizontally onto the stations in between. Using this concentration field, the mean concentration for each watermass was computed for the T-S ranges shown in Fig. 3, which avoids mean concentrations being dependent on the

380 number of measurements. The results show substantial differences in phosphate between the years, some differences in nitrate, and fairly constant silicate concentrations (Table 1). DIC appears to be quite constant, but one has to consider that its concentration is strongly salinity-dependent. When the WW concentrations are corrected for the salinity difference, the 2014 
https://doi.org/10.5194/os-2021-43

Preprint. Discussion started: 25 May 2021

DIC concentration becomes $20 \mu \mathrm{mol} \mathrm{kg}{ }^{-1}$ higher than in 2008 and for the BSW the concentration becomes $31 \mu \mathrm{mol} \mathrm{kg}{ }^{-1} \mathrm{higher}$ When these differences in concentration are multiplied with the classical Redfield-Ketchum-Richards ratios 1:16:106 for P:N:C (Redfield et al., 1963), they correspond to a shift in phosphate of 0.19 and $0.30 \mu \mathrm{mol} \mathrm{L}^{-1}$ for WW and BSW, respectively, and in nitrate of 3.0 and $4.7 \mu \mathrm{mol} \mathrm{\textrm {L } ^ { - 1 }}$ for $\mathrm{WW}$ and BSW, respectively. These are significant differences relative to those observed in phosphate and nitrate. Utilizing the mean concentrations of Table 1 together with the volume transport of Table 2 , net property transport across the different sections and years are computed (Table 3). Using the 37-year mean modeled volume transports of Fig. 11, the transports of Table 3 would roughly halve for the WW and more or less vanish for BSW.

Table 3: Transport of nutrients and DIC on a daily basis based on the measured data for the different sections, units are in $10^{8}$ mole day ${ }^{-1}$. Volume transports are the total from Table 2.

\begin{tabular}{llccccc}
\hline & Year & 2008 & 2008 & 2008 & 2014 & 2014 \\
& Section & 1 & 2 & 3 & 3 & 4 \\
\hline Silicate & WW & -0.6 & 6.5 & -7.8 & 1.9 & 12.3 \\
& BSW & 2.9 & 0.5 & -0.5 & 1.0 & 0.7 \\
\hline Nitrate & WW & -0.2 & 2.2 & -2.7 & 0.5 & 3.5 \\
& BSW & 1.3 & 0.2 & -0.2 & 0.4 & 0.3 \\
\hline Phosphate & WW & -0.04 & 0.4 & -0.5 & 0.08 & 0.5 \\
& BSW & 0.4 & 0.07 & -0.07 & 0.1 & 0.07 \\
\hline DIC & WW & -37 & 370 & -448 & 104 & 671 \\
& BSW & 528 & 92 & -97 & 215 & 149 \\
\hline
\end{tabular}

\section{Discussion}

WW in 2014 was significantly fresher than in 2008. However, the larger volume of this watermass present in Herald Canyon in 2014 led to a further eastward extent compared to 2008 (Figs. 4cd, 11cd). There was an extreme sea ice minimum in 2007, especially in the East Siberian and Chukchi Seas (Comiso et al., 2008). The sea ice cover re-formed more slowly in OctoberDecember 2007 than in October-December 2013 with weaker heat loss from ocean to atmosphere in autumn 2007 (Fig. 13). Winds over the Chukchi Sea are generally northeasterly in winter, piling water against the Siberian coast and preventing its northward flow until winds weaken in spring (Pickart et al., 2010). During autumn and early winter 2013/14 winds were more westerly than in 2007/08 tending to drive water off the East Siberian shelf (Fig. 13). The resulting reduction in residence time could potentially reduce the salinity enhancement of the shelf waters due to brine release during sea ice formation, leading to a larger volume of fresher WW being formed in winter 2013/14. Despite weaker heat loss in winter 2007/08, the longer residence time on the East Siberian shelf allowed the formation of a smaller volume of more saline WW. In addition, the large- 
https://doi.org/10.5194/os-2021-43

Preprint. Discussion started: 25 May 2021

(c) Author(s) 2021. CC BY 4.0 License.

scale freshening of the Arctic Ocean over recent decades, particularly in the Canada Basin (Haines et al., 2015) may have contributed to the difference in WW salinities between 2008 and 2014. The observed (and modelled) freshening of the WW in 2014 reduces its density sufficiently to weaken the density front between WW and BSW across Herald Canyon potentially enhancing the exchange between the water masses (Figs. 4, 7).
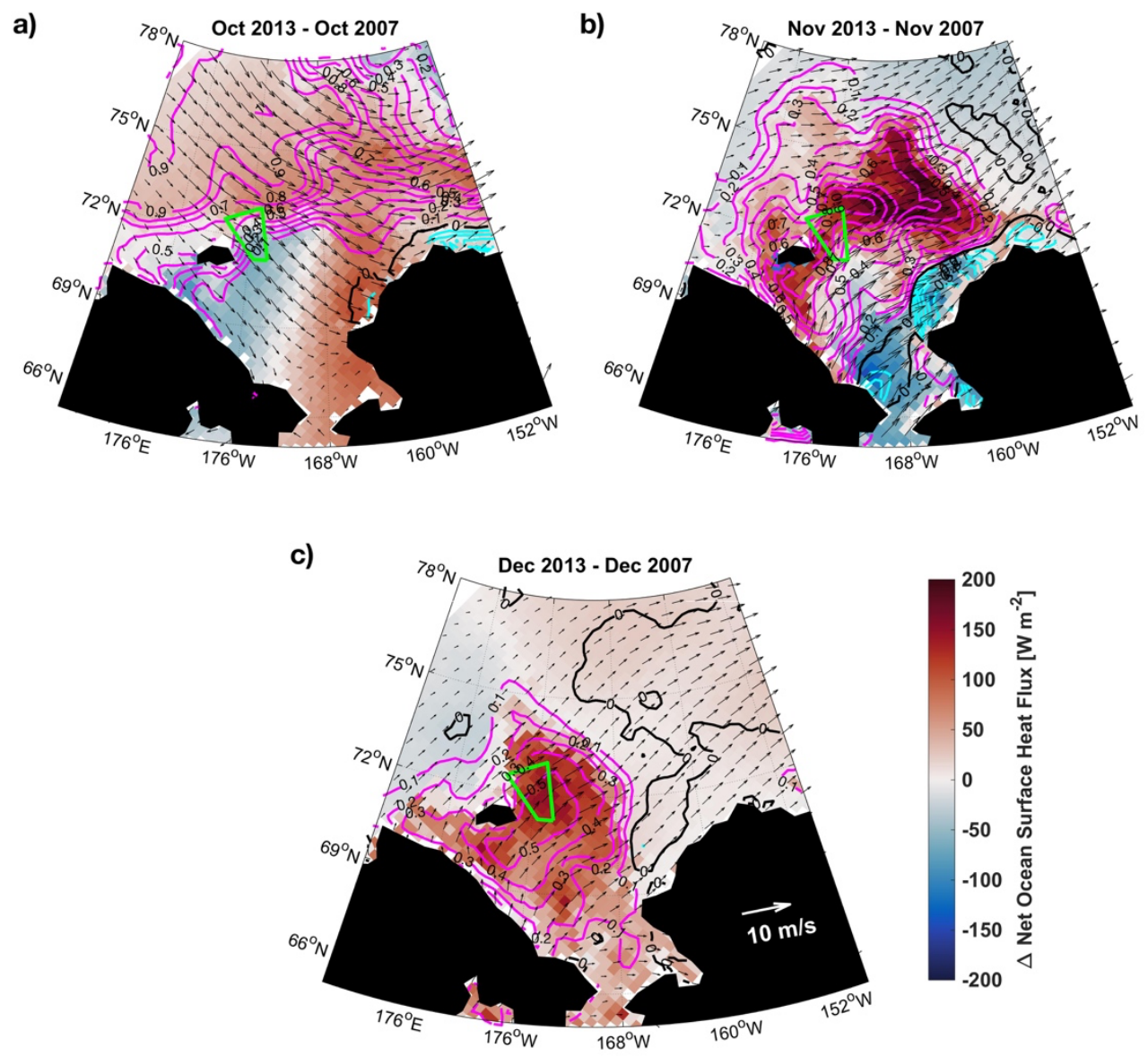

Figure 13: Difference in wind velocities (black vectors), sea ice concentration (contours, magenta positive anomalies, i.e. more sea 410 ice in 2013, cyan negative anomalies), and net ocean surface heat flux (shaded) for the autumn and winter sea ice growth season preceding the two cruises. Heat fluxes are defined positive upward, i.e., positive anomalies correspond to a larger heat loss by the ocean in 2013. Monthly means for a) October 2013 - October 2007, b) November 2013 - November 2007, c) December 2013 December 2007.

Modelled volume transport showed a large range of variability in Herald Canyon on a daily timescale (Fig. 8). Flow reversals 415 were common and occurred during August-September of both 2008 and 2014. This is consistent with observational data from 1990-1991 in Herald Canyon, which showed flow reversals lasting a week or more that were correlated with the wind field (Woodgate et al., 2005). Synoptic storms enter the Chukchi Sea frequently during the late summer/fall time period and are a driving force for the flow in Herald Canyon (Pickart et al., 2010). The ocean component of RASM is coupled to a relatively 
https://doi.org/10.5194/os-2021-43

Preprint. Discussion started: 25 May 2021

(c) Author(s) 2021. CC BY 4.0 License.

high-resolution atmospheric component within the system model, however errors in the representation of atmospheric fields

420 would likely be in the direction of underrepresentation of the strength of storms. This leads us to conclude that the large variability in modelled flow is valid and that short-term measurements of the speed and direction of the flow are not necessarily representative of the mean over time.

The currents computed from the observations, as well as the numerical modeling results, show southward flowing water in the 425 western Herald Canyon (Figs. 4 and 7). This southward-flowing water most likely has the East Siberian Sea as a source which is supported by the hydrographic signature of the water as well as the general circulation from the model results (Fig. 7). It has high nutrient concentrations, typical for decay of organic matter, but not high enough salinity to come from any substantial depth along the continental margin (Fig. 14a). Also, its temperatures are close to the freezing point, significantly lower than the temperature of water at the shelf break with the same high silicate concentration (Fig. 14b). Furthermore, it has a higher 430 oxygen concentration than the slope water at the high silicate concentration ( $>40 \mu \mathrm{mol} \mathrm{L}-1)$, as exemplified by the 2014 data in Figure 14c. The only exception is the deepest water in the northern section, with silicate concentrations above $70 \mu \mathrm{mol} \mathrm{L}^{-1}$; water that most likely includes some intrusions of the slope current as it also has higher salinity and temperature compared to the WW. 
https://doi.org/10.5194/os-2021-43

Preprint. Discussion started: 25 May 2021

(c) Author(s) 2021. CC BY 4.0 License.

(a)

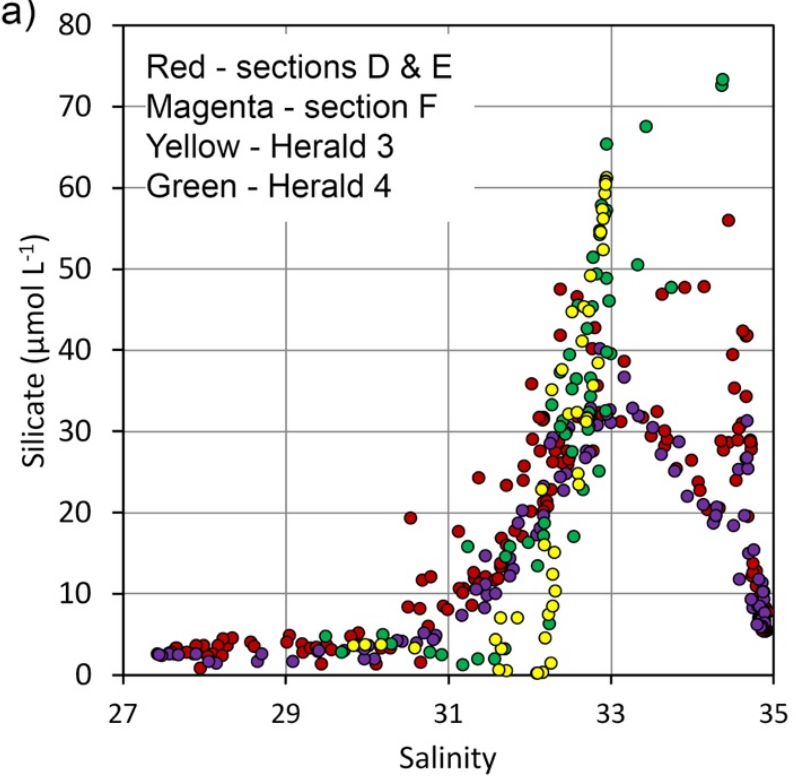

(c)

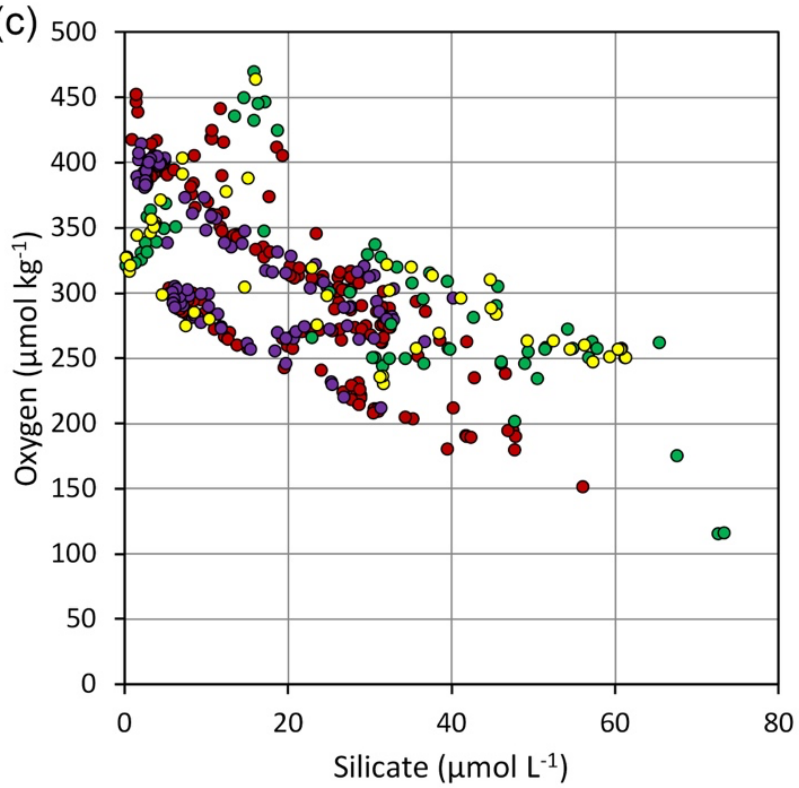

(b)

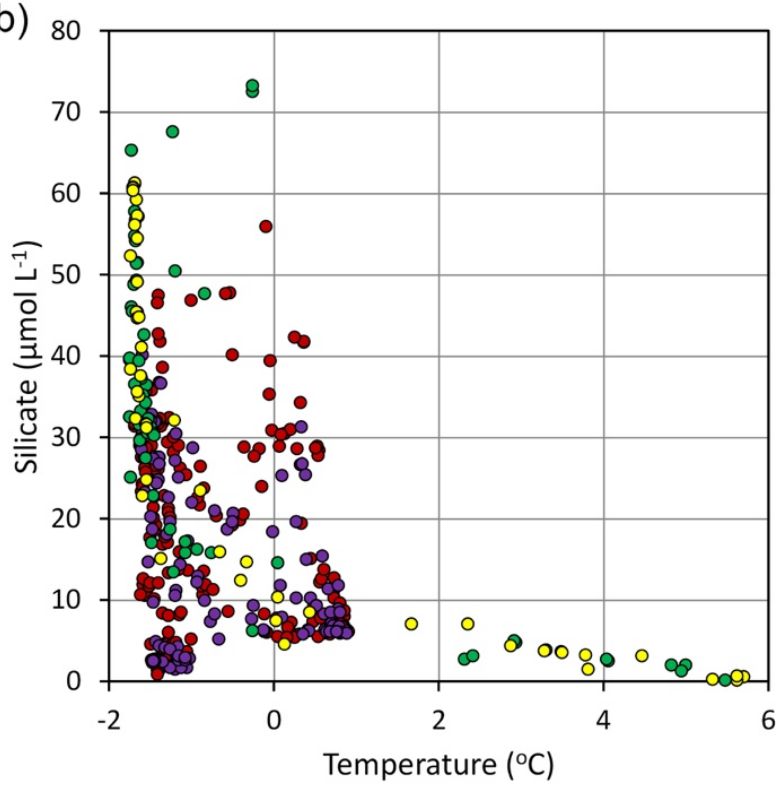

435 Figure 14. Plots of SWERUS-C3 East Siberian Sea shelf break data compared with those of Herald Canyon: Silicate versus salinity (a), silicate versus temperature (b) and oxygen versus silicate (c). Locations of the stations noted in the map of Fig. 1 b.

Winsor and Bjork (2000) used a polynya model driven by atmospheric forcing to compute ice, salt, and dense water production in different regions of the Arctic Ocean over 39 winter seasons from 1958 to 1997. The area west of Wrangel Island was one region where many polynyas formed and created high salinity waters from brine produced by ice formation. 
https://doi.org/10.5194/os-2021-43

Preprint. Discussion started: 25 May 2021

Another aspect is the fate of the southward-flowing water to the western Herald Canyon; is it recirculating within Herald Canyon or is it flowing around Wrangel Island back into the East Siberian Sea? Our observational data can not reveal this, but as most of the high nutrient water is deeper than $50 \mathrm{~m}$, a depth that to our knowledge exceeds that south of Wrangel Island, the most plausible conclusion is a recirculation in the canyon. Also, there are some indications of two cores of high nutrient water in 2014 at section 3, one in the west on the shallower part and one in the deep central canyon (Fig. 12 b, d, f), that could be a result of one south and one north flowing core.

When assuming that the southward flowing water recirculates in Herald Canyon it also means that the net flux gives the total transport within the geographic range of the section, i.e. if the water that recirculates is included in the north-flowing current. Hence the transports of Table 3 represent snapshots of the supply to the north. It should be noted that this section does not cover all waters that flow either to the south or to the north and thus comes with substantial uncertainties. However, Fig. 5a suggests that more of the northward flow is missed, which indicate that the transports are underestimated. The supply of nutrients contributing to new primary production in the central Arctic Ocean in 2014 can be computed from the transport at section 4 (Table 3), the most northerly and thus the one that might best represent the flux into the deep basins. Adding together

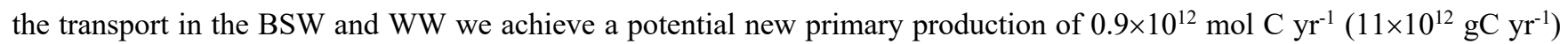

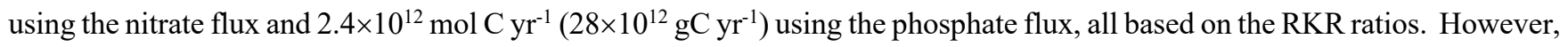
these numbers have to be taken with care as the model annual average volume transport of BSW and WW in section 3 only was $15 \%$ of the computed from the measured properties. It is evident, though, that nitrate is the limiting element and that a

460 volume transport of $0.431 \mathrm{~Sv}$ (Table 1) makes a major contribution to the fueling of primary production in this region of the Arctic Ocean. For instance, Anderson et al. (2003) used the phosphate deficit in the central Arctic Ocean to compute an export

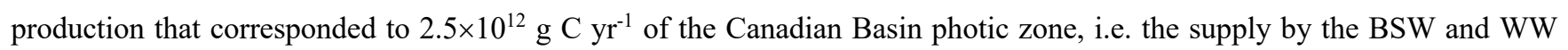
could contribute 5 times this export if it reached the photic zone. However, this is not expected, at least not under the present oceanographic conditions, but points to the importance of the transport through the Herald Canyon as a source of nutrients to

465 the central Arctic Ocean. High values of primary production were also modelled in Long Strait and much of the East Siberian Sea during June 2011 (Clement Kinney et al., 2020), apparently driven by a northwestward flow through Long Strait. The arrival of high-nutrient water from the western side of Bering Strait when combined with accelerated early sea ice melt created conditions that were favorable to primary production in the East Siberian Sea.

\section{Conclusions}

470 Numerical modelling results show that a substantial fraction of Pacific Water that enters the Chukchi Sea through the Bering Strait continues into the East Siberian Sea via Long Strait south of Wrangel Island. Both the model results and hydrographic conditions support that some of this water flows north of Wrangel Island back into the Chukchi Sea and is entrained in the 
https://doi.org/10.5194/os-2021-43

Preprint. Discussion started: 25 May 2021

northward-flowing water of Herald Canyon that supplies the halocline of the central Arctic Ocean. The net transport in Herald Canyon, at a section located about $72^{\circ} 20^{\prime} \mathrm{N}$, was computed based on observations in September 2008 to be about $0.3 \mathrm{~Sv}$ to the South, of which $\sim 80 \%$ had WW properties, while $\sim 20 \%$ was BSW. In August 2014, on the other hand, corresponding computations gave a transport to the North of $0.24 \mathrm{~Sv}$ of which $\sim 20 \%$ was WW and $\sim 50 \%$ was BSW, with the remaining $\sim 30 \%$ being surface waters. This large variability in transport, including a change in the direction, points to the flow in Herald Canyon being highly variable in time and space, a result of the shallow water environment being sensitive to the wind and sea ice conditions. This is also illustrated by the simulated daily modelled net volume transport for the same section that ranged from - 0.4 to $0.4 \mathrm{~Sv}$ (negative is southward) with a mean of $0.109 \mathrm{~Sv}$ over the 2-month period of August-September 2008, while it ranged between $-0.5 \mathrm{~Sv}$ to $0.35 \mathrm{~Sv}$ with a mean of $-0.007 \mathrm{~Sv}$ for the same months in 2014. A long-term perspective for the period 1980-2017 indicates a modelled mean transport of 0.032 Sv northward for all water masses combined, which includes a northward component of $0.063 \mathrm{~Sv}$ and a southward of $0.031 \mathrm{~Sv}$. However, the maximum monthly transports are up to 0.2 $\mathrm{Sv}$ to the north and nearly as much to the south. The BSW transport has a relatively evident seasonal signal with the strongest transport in the fall months, also with a tendency for an increasing transport during the last decade. The WW transport on the other hand does not show any seasonal pattern.

The nutrient concentrations in the WW were on the order of $2 \mu \mathrm{mol} \mathrm{L} \mathrm{L}^{-1}$ for phosphate and $12 \mu \mathrm{mol} \mathrm{L} \mathrm{L}^{-1}$ for nitrate, with lower values observed in the BSW. Thus, Herald Canyon is a substantial conveyor of nutrients to the Arctic Ocean and using the volume transport computed from measurements at the most northern section it could support a new primary production of

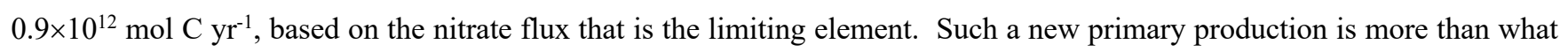
has been reported for the Canadian Basin, but one should note that not all of the nutrients in the WW will enter the photic zone in a short time-perspective, and also the measured water volume transport is only $15 \%$ of the average modelled. Nevertheless, the nutrient supply through the Herald Canyon is important for primary production and appears to be a source for under-ice phytoplankton blooms that have been observed (Arrigo et al., 2012) and modelled (Clement Kinney et al., 2020) within the canyon and to the north. This investigation shows the highly dynamic conditions in the western Chukchi Sea and pinpoints a need for long-term monitoring of transport and biochemical properties in Herald Canyon, in order to better understand its role in supply to the central Arctic Ocean and to validate model results.

\section{Data availability}

500 CTD data can be accessed at the World Data Center PANGAEA. Chemical and Bathymetric data can be accessed at Bolin Centre Data Base, Stockholm University http://bolin.su.se/data/. The daily 10 m NCEP North American Regional Reanalysis NARR winds and monthly mean surface heat fluxes were downloaded from ftp://ftp.cdc.noaa.gov/Datasets/NARR/Dailies/monolevel/. 
https://doi.org/10.5194/os-2021-43

Preprint. Discussion started: 25 May 2021

505 Acknowledgements

The science was financially supported by: US National Science Foundation (Grant Number: GEO/PLR ARCSS IAA\#1417888), the Department of Energy (DOE) Regional and Global Model Analysis (RGMA), the Swedish Research Council Formas (contract no 2018-01398), and the Swedish Research Council (contract no 621-2006-3240, 621-2010-4084, and 2012-1680). This work was carried out with logistic support from the Knut and Alice Wallenberg Foundation and from

510 Swedish Polar Research Secretariat. The Department of Defense (DOD) High Performance Computer Modernization Program (HPCMP) provided computer resources. We thank Steve Okkonen for providing a helpful review of an early version of this manuscript.

\section{References}

515 Anderson, L. G., Jones, E. P., and Swift, J. H.: Export production in the central Arctic Ocean as evaluated from phosphate deficit, J. Geophys. Res., 108(C6), 3199, doi:10.1029/2001JC001057, 2003.

Anderson, L. G., Björk, G., Jutterström, S., Pipko, I., Shakhova, N., Semiletov, I. P., and Wåhlström, I.: East Siberian Sea, an Arctic region of very high biogeochemical activity, Biogeosciences, 8, 1745-1754, doi:10.5194/bg-8-1745-2011, 2011.

Arrigo, K. R., Perovich, D. K., Pickart, R. S., Brown, Z. W., Dijken, G. L. Van, Lowry, K. E., Mills, M. M., Palmer, M. A., Balch, W. M., Bahr, F., Bates, N. R., Benitez-nelson, C., Bowler, B., Brownlee, E., Ehn, J. K., Frey, K. E., Garley, R., Laney, S. R., Lubelczyk, L., ... Swift, J. H.: Massive phytoplankton blooms under Arctic sea ice. Science, 336, 1408, 2012.

Arrigo, K. R., and van Dijken, G. L.: Continued increases in Arctic Ocean primary production, Prog. Oceanogr. 136, 60-70. doi: 10.1016/j.pocean.2015.05.002, 2015.

Björk, G., Jakobsson, M., Anderson, L. G., Nilsson, J., Stranne, C., Assmann, K., Mayer, L.: Bathymetry and oceanic flow structure at two deep channels crossing the Lomonosov Ridge, Ocean Sci., 14, 1-13, doi:10.5194/os-14-1-2018, 2018

Brugler, E.T., Pickart, R. S., Moore, G. W. K., Roberts, S., Weingartner, T. J., Statscewich, H.: Seasonal to interannual variability of the Pacific water boundary current in the Beaufort Sea, Prog. Oceanogr., 127, 1-20, doi.org/10.1016/j.pocean.2014.05.002, 2014.

Brunke, M. A., Cassano, J. J., Dawson, N., Duvivier, A. K., Gutowski, W. J., Hamman, J., Maslowski, W., Nijssen, B., Jack Reeves Eyre, J. E., Renteria, J. C., Roberts, A., \& Zeng, X.: Evaluation of the atmosphere-land-ocean-sea ice interface processes in the Regional Arctic System Model version 1 (RASM1) using local and globally gridded observations, Geosci. Model Dev., 11(12), 4817-4841. https://doi.org/10.5194/gmd-11-4817-2018, 2018.

Cassano, J. J., DuVivier, A., Roberts, A., Hughes, M., Seefeldt, M., Brunke, M., Craig, A., Fisel, B., Gutowski, W., Hamman, J., Higgins, M., Maslowski, W., Nijssen, B., Osinski, R., \& Zeng, X.: Development of the Regional 
https://doi.org/10.5194/os-2021-43

Preprint. Discussion started: 25 May 2021

(c) Author(s) 2021. CC BY 4.0 License.

Arctic System Model (RASM): Near-surface atmospheric climate sensitivity, J. Climate, 30(15), 5729-5753, https://doi.org/10.1175/JCLI-D-15-0775.1, 2017.

Cavalieri, D. J., Parkinson, C. L., Gloersen, P., and Zwally H. J.: Sea Ice Concentrations from Nimbus-7 SMMR and DMSP SSM/I-SSMIS Passive Microwave Data, Version 1. Boulder, Colorado USA. NASA National Snow and Ice Data Center Distributed Active Archive Center. https://doi.org/10.5067/8GQ8LZQVL0VL. 1996, updated yearly. [Accessed 09 March 2016].

Clement, J. L., Maslowski, W., Cooper, L., Grebmeier, J., Walczowski, W.: Ocean circulation and exchanges through the northern Bering Sea - 1979-2001 model results. Deep-Sea Res. Pt. II, 52, 3509-3540, doi: 10.1016/j.dsr2.2005.09.010, 2005.

Clement Kinney, J., Maslowski, W., Aksenov, Y., de Cuevas, B., Jakacki, J., Nguyen, A., Osinski, R., Steele, M., Woodgate, R. A., Zhang, J.: On the Flow Through Bering Strait: A Synthesis of Model Results and Observations, in: The Pacific Arctic Region: Ecosystem Status and Trends in a Rapidly Changing Environment, edited by: Grebmeier J. M. and Maslowski, W., Springer, New York, USA, 167-189, 2014.

Clement Kinney, J., Maslowski, W., Osinski, R., Jin, M., Frants, M., Jeffery, N., Lee, Y.: Hidden production: On the importance of pelagic phytoplankton blooms beneath Arctic sea ice, J. Geophys. Res.-Oceans, 125(9), doi.org/10.1029/2020JC016211, 2020.

Coachman, L. K., Aagaard, K., and Tripp, R. B.: Bering Strait: The Regional Physical Oceanography. Univ. of Wash. Press, Seattle. 172 pp, 1975.

Comiso, J. C., Parkinson, C. L., Gersten, R., and Stock, L.: Accelerated decline in the Arctic sea ice cover, Geophys. Res. Lett., 35, L01703, doi:10.1029/2007GL031972, 2008.

Craig A. P., Vertenstein M., and Jacob R.: A new flexible coupler for earth system modeling developed for CCSM4 and CESM1. Int J High Perform Comput Appl. 26(1), 31-42, 2012.

Ding, Q., Schweiger, A., L'Heureux, M. et al.: Influence of high-latitude atmospheric circulation changes on summertime Arctic sea ice. Nat. Clim. Change 7, 289-295, https://doi.org/10.1038/nclimate3241, 2017.

DuVivier, A. K., Cassano, J. J., Craig, A., Hamman, J., Maslowski, W., Nijssen, B., Osinski, R., and Roberts, A.: Winter atmospheric buoyancy forcing and oceanic response during strong wind events around southeastern Greenland in the Regional Arctic System Model (RASM) for 1990-2010, J. Climate, 29(3), 975-994. https://doi.org/10.1175/JCLI-D-15-0592.1, 2016.

Haine, T. W. N., B. Curry, R. Gerdes, E. Hansen, M. Karcher, C. Lee, B. Rudels, G. Spreen, L. de Steur, K. D. Stewart, R. Woodgate: Arctic freshwater export: Status, mechanisms, and prospects, Global and Planetary Change, 125, 13 35, doi: 10.1016/j.gloplacha.2014.11.013, 2015.

Hamman, J., Nijssen, B., Brunke, M., Cassano, J., Craig, A., DuVivier, A., Hughes, M., Lettenmaier, D. P., Maslowski, W., Osinski, R., Roberts, A., and Zeng, X.: Land surface climate in the regional Arctic system model. J. Climate, 
https://doi.org/10.5194/os-2021-43

Preprint. Discussion started: 25 May 2021

29(18), 6543-6562. https://doi.org/10.1175/JCLI-D-15-0415.1, 2016.

Hamman, J., Nijssen, B., Roberts, A., Craig, A., Maslowski, W., and Osinski, R.: The coastal streamflow flux in the Regional Arctic System Model. J. Geophys. Res.-Oceans, 122, 1683-1701. https://doi.org/doi:10.1002/2016JC012323, 2017.

Jakobsson, M., Mayer, L. A., Bringensparr, C., Castro, C. F., Mohammad, R., Johnson, P., Ketter, T., Accettella, D., Amblas, D., An, L., Arndt, J. E., Canals, M., Casamor, J. L., Chauché, N., Coakley, B., Danielson, S., Demarte, M., Dickson, M.-L., Dorschel, B., Dowdeswell, J. A., Dreutter, S., Fremand, A. C., Gallant, D., Hall, J. K., Hehemann, L., Hodnesdal, H., Hong, J., Ivaldi, R., Kane, E., Klaucke, I., Krawczyk, D. W., Kristoffersen, Y., Kuipers, B. R., Millan, R., Masetti, G., Morlighem, M., Noormets, R., Prescott, M. M., Rebesco, M., Rignot, E., Semiletov, I., Tate, A. J., Travaglini, P., Velicogna, I., Weatherall, P., Weinrebe, W., Willis, J. K., Wood, M., Zarayskaya, Y., Zhang, T., Zimmermann, M. and Zinglersen, K. B.: The International Bathymetric Chart of the Arctic Ocean Version 4.0. Scientific Data, 7, 176, 10.1038/s41597-020-0520-9, 2020.

Jin, M., Deal, C., Maslowski, W., Matrai, P., Roberts, A., Osinski, R., Lee, Y. J., Frants, M., Elliott, S., Jeffery, N., Hunke, E., \& Wang, S.: Effects of Model Resolution and Ocean Mixing on Forced Ice-Ocean Physical and Biogeochemical Simulations Using Global and Regional System Models. J. Geophys. Res.-Oceans, 123(1), 358-377. https://doi.org/10.1002/2017JC013365, 2018.

Johnson, K. M., Sieburth, J. M., Williams, P. J., and Brändström, L.: Coulometric total carbon dioxide analysis for marine studies: automation and calibration, Mar. Chem. 21, 117-133, 1987.

Kaltin, S., and Anderson, L. G.: Uptake of atmospheric carbon dioxide in Arctic shelf seas: evaluation of the relative importance of processes that influence $\mathrm{pCO}_{2}$ in water transported over the Bering-Chukchi Sea shelf. Mar. Chem., 94, 67-79, 2005.

Kashiwase, H., Ohshima, K.I., Nihashi, S. et al.: Evidence for ice-ocean albedo feedback in the Arctic Ocean shifting to a seasonal ice zone, Sci. Rep. 7, 8170, https://doi.org/10.1038/s41598-017-08467-z, 2017.

Kwok, R.: Arctic sea ice thickness, volume, and multiyear ice coverage: losses and coupled variability (1958-2018) Environ. Res. Lett., 13 105005. https://doi.org/10.1088/1748-9326/aae3ec, 2018.

Leng, H., Spall, M. A., R. S. Pickart, Lin, P., Bai, X.,: Origin and Fate of the Chukchi Slope Current Using a Numerical Model and In-situ Data, J. Geophys. Res.-Oceans, https://doi.org/10.1029/2021JC017291.

Linders, J., Pickart, R. S. Björk, G., and Moore, G. W. K.: On the nature and origin of water masses in Herald Canyon, Chukchi Sea: Synoptic surveys in summer 2004, 2008, and 2009, Prog. Oceanogr., 159, 99-114, http://dx.doi.org/10.1016/j.pocean.2017.09.005, 2017.

Maslowski, W. E., et al.: The Large Scale Ocean Circulation and Physical Processes Controlling Pacific-Arctic Interaction, in: The Pacific Arctic Region: Ecosystem Status and Trends in a Rapidly Changing Environment, edited by Grebmeier, J. M., and Maslowski, W. E., Springer, New York, USA, 101-132, 2014. 
https://doi.org/10.5194/os-2021-43

Preprint. Discussion started: 25 May 2021

(c) Author(s) 2021. CC BY 4.0 License.

McDougall, T.J. and Barker, P.M.: Getting started with TEOS-10 and the Gibbs Seawater (GSW) Oceanographic Toolbox, 28pp., SCOR/IAPSO WG127, ISBN 978-0-646-55621-5, 2011.

Meier, W. N., et al.: Arctic sea ice in transformation: A review of recent observed changes and impacts on biology and human activity, Rev. Geophys., 52, 185-217, doi:10.1002/2013RG000431, 2014.

Mesinger, F., DiMego, G., Kalnay, E., Mitchell, K., Shafran, P.C., Ebisuzaki, W., Jović, D., Woollen, J., Rogers, E., Berbery, E.H., Ek, M.B., Fan, Y., Grumbine, R., Higgins, W., Li, H., Lin, Y., Manikin, G., Parrish, D., Shi, W.: North American regional reanalysis, Bull. Am. Meteorol. Soc. 87, 343-360. http://dx.doi.org/10.1175/BAMS-87-3343, 2006.

Mills, M. M., Brown, Z. W., Laney, S. R., Ortega-Retuerta, E., Lowry, K. E., Van Dijken, G. L., and Arrigo, K. R.: Nitrogen limitation of the summer phytoplankton and heterotrophic prokaryote communities in the Chukchi Sea, Frontiers in Marine Science, 5, 362, 2018.

615 Padman, L., and Erofeeva, S.: A barotropic inverse tidal model for the Arctic Ocean, Geophys. Res. Lett., 31(2), L02303, doi:10.1029/2003GL019003, 2004.

Pickart, R.S., Pratt, L.J., Torres, D.J., Whitledge, T.E., Proshutinsky, A.Y., Aagaard, K., Agnew, T.A., Moore, G.W.K., Dail, H.J.: Evolution and dynamics of the flow through Herald Canyon in the Western Chukchi Sea, Deep-Sea Res. Pt. II, $57,5-26,2010$.

Pisareva, M. N., Pickart, R. S., Spall, M. A., Nobre, C., Torres, D. J., Moore, G. W. K., and Whitledge, T. E.: Flow of pacific water in the western Chukchi Sea: Results from the 2009 RUSALCA expedition, Deep-Sea Res. Pt. I, 105, p. 5373, doi.org/10.1016/j.dsr.2015.08.011, 2015.

Polyakov, I. V., Pnyushkov, A. V., Alkire, M. B., Ashik, I. M., Baumann, T. M., Carmack, E. C., Goszczko, I., Guthrie, J., Ivanov, V. V., Kanzow, T., Krishfield, R., Kwok, R., Sundfjord, A., Morison, J., Rember, R., Yulin, A.: Greater role for Atlantic inflows on sea ice loss in the Eurasian Basin of the Arctic Ocean, Science, 356, 285-291, doi:10.1126/science.aai8204, 2017.

Polyakov, I. V., Pnyushkov, A. V., Rember, R., Padman, L., Carmack, E. C., and Jackson, J. M.: Winter convection transports Atlantic water heat to the surface layer in the Eastern Arctic Ocean, J. Phys. Oceanogr. 43 2142-55, 2013.

630 Redfield, A. C., Ketchum, B. H., \& Richards, F. A.: The influence of organisms on the composition of seawater, in: The Sea, Vol 2, edited by: Hill, M. N., Wiley, New York, USA, 26-77, 1963.

Roberts, A., Craig, A., Maslowski, W., Osinski, R., Duvivier, A., Hughes, M., Nijssen, B., Cassano, J., and Brunke, M.: Simulating transient ice-ocean Ekman transport in the Regional Arctic System Model and Community Earth System Model, Ann. Glaciol., 56(69), 211-228. https://doi.org/10.3189/2015AoG69A760, 2015.

635 Roberts, A. F., Hunke, E. C., Allard, R., Bailey, D. A., Craig, A. P., Lemieux, J.-F., and Turner, M. D.: Quality control for community-based sea-ice model development, Philos. T. Roy. Soc. A, 376, 1-18. https://doi.org/http://dx.doi.org/10.1098/rsta.2017.0344, 2018. 
https://doi.org/10.5194/os-2021-43

Preprint. Discussion started: 25 May 2021

(c) Author(s) 2021. CC BY 4.0 License.

Stroeve, J., and Notz, D.: Changing state of Arctic sea ice across all seasons, Environ. Res. Lett., 13, 103001, https://doi.org/10.1088/1748-9326/aade56, 2018.

640 Thurnherr, A. M., Visbeck, M., Firing, E., King, B. A., Hummon, J. M., Krahmann, G. K., and Huber, B.: A Manual for acquiring Lowered Doppler Current Profiler Data, IOCCP Report No. 14, ICPO Publication Series No.134, Version $1,2010$.

von Appen, W. J., Schauer, U., Somavilla, R., Bauerfeind, E., \& Beszczynska-Möller, A.: Exchange of warming deep waters across Fram Strait, Deep-Sea Res. Pt. I, 103, 86-100, 2015.

645 Wang, Q., Wekerle, C., Wang, X., Danilov, S., Koldunov, N., Sein, D., Sidorenko, D., vonAppen, W.-J., and Jung, T.: Intensification of the Atlantic Water supply to the Arctic Ocean through Fram Strait induced by Arctic sea ice decline, Geophys. Res. Let., 47, e2019GL086682. https://doi.org/10.1029/2019GL086682, 2020.

Weingartner, T. J., Danielson, S., Sasaki, Y., Pavlov, V., Kulakov, M.: The Siberian Coastal Current. A wind- and buoyancy-forced Arctic coastal current, J. Geophys. Res.-Oceans, 104, 29697-29713, 1999.

Williams, W. J., and Carmack, E. C.: The 'interior' shelves of the Arctic Ocean: Physical oceanographic setting, climatology and effects of sea-ice retreat on cross-shelf exchange, Prog. Oceanogr., 139, 24-41, https://doi.org/10.1016/j.pocean.2015.07.008, 2015.

Wilson, C., and Wallace, D. W. R.: Using the nutrient ratio NO/PO as a tracer of continental shelf water in the central Arctic Ocean, J. Geophys. Res., 95, 22 193-22 203, 1990.

655 Winsor, P., and Björk, G.: Polynya activity in the Arctic Ocean from 1958 to 1997, J. Geophys. Res., 105, C4, 8789-8803, 2000.

Woodgate, R. A., Aagaard, K., and Weingartner, T. J.: A year in the physical oceanography of the Chukchi Sea: Moored measurements from autumn 1990-1991, Deep-Sea Res. Pt. II, 52, 3116-3149, 2005.

Woodgate, R. A., Stafford, K. M., and Prahl, F. G.: A Synthesis of Year-Round Interdisciplinary Mooring Measurements in the Bering Strait (1990-2014) and the RUSALCA Years (2004-2011), Oceanography, v. 28, no. 3, p. 46-67, 2015.

Woodgate, R. A. Increases in the Pacific inflow to the Arctic from 1990 to 2015, and insights into seasonal trends and driving mechanisms from year-round Bering Strait mooring data, Prog. in Oceanogr., https://doi.org/10.1016/j.pocean.2017.12.007, 2018.

Woodgate, R. A., \& Peralta-Ferriz, C.: Warming and freshening of the Pacific inflow to the Arctic from 1990-2019 implying dramatic shoaling in Pacific Winter Water ventilation of the Arctic water column, Geophys. Res. Lett., 48, e2021GL092528. https://doi.org/10.1029/2021GL092528, 2021. 